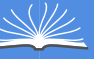

Global Journals In

(

\title{
Wonder Findings of Number of Cells in a Body Including Sexual Cells, Remedy of Corona Virus, Increase of Memory, And other Cells by Couple System
}

By Nirmalendu Das

Abstract- It is difficult to calculate fixed data of a number of cells in a body. It is varying on time and age of life. The time increasing that cells are increasing, though we can estimate the number of cells in various nerves in a body, brain, sexual platform, etc through a couple system. The coupling system is a new system of the finding of peculiar series of numbers [1], which is applies to many fields. In the cases of Medical Science, it has been observed by calculation that due to disturbing of the couple caused different difficulties in the body. A smooth Coupling cell may produce a healthy body, and it is possible to increase memory by adding particular cells number in a loss position. The coupling system is interesting that, can explain the real mechanism of every cell. There are many types of cells in a living body. Almost all cells follow a couple of system. The coupling system performs coupling between two (say, A, 1st party \& B, 2nd party) with keeping relation as 3rd party, denoted by $\mathrm{R}$ (Relative Number) mathematically.

Keywords: number of cells related to couple system, sexual activity, corona virus, cancer cells, neurons of humans \& animals, cause of diseases, memory cells.

GJSFR-C Classification: FOR Code: 279999

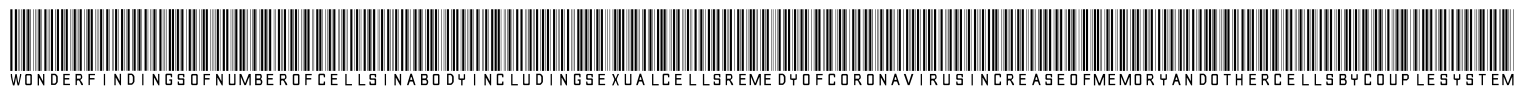

Strictly as per the compliance and regulations of:

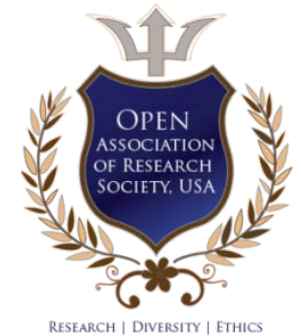

(c) 2020. Nirmalendu Das. This is a research/review paper, distributed under the terms of the Creative Commons AttributionNoncommercial 3.0 Unported License http://creativecommons.org/licenses/by-nc/3.0/), permitting all non commercial use, distribution, and reproduction in any medium, provided the original work is properly cited. 


\title{
Wonder Findings of Number of Cells in a Body Including Sexual Cells, Remedy of Corona Virus, Increase of Memory, And other Cells by Couple System
}

\author{
Nirmalendu Das
}

Abstract- It is difficult to calculate fixed data of a number of cells in a body. It is varying on time and age of life. The time increasing that cells are increasing, though we can estimate the number of cells in various nerves in a body, brain, sexual platform, etc through a couple system. The coupling system is a new system of the finding of peculiar series of numbers [1], which is applies to many fields. In the cases of Medical Science, it has been observed by calculation that due to disturbing of the couple caused different difficulties in the body. A smooth Coupling cell may produce a healthy body, and it is possible to increase memory by adding particular cells number in a loss position. The coupling system is interesting that, can explain the real mechanism of every cell. There are many types of cells in a living body. Almost all cells follow a couple of system. The coupling system performs coupling between two (say, A, 1st party \& B, 2nd party) with keeping relation as 3rd party, denoted by $R$ (Relative Number) mathematically. This system applies to finding the series of Pi [1], 1/2 values [2], Searching of Properties of Mind, Activity of number of Cells in a brain [3]; Determination of relative numbers by using couple system and its application to the atomic fields and quark coupling strength of the LHCb collaboration [4]. We can determine the atomic number, electron, proton, neutron, splitting of quark from one point to other, etc. So, we can call this system to give birth to all systems. It requires more study and searches in every case, couple system in medical science a touch of light that can bring a revolutionary change to keep fit body from various virus effects.

Keywords: number of cells related to couple system, sexual activity, corona virus, cancer cells, neurons of humans \& animals, cause of diseases, memory cells.

\section{INTRODUCTION}

- he process of the birth of the body is a natural system. Cell forms accordingly by nature. It has seemed that all processes of birth probably follow one relation to the next relation by coupling each other. Figure 1[5], is indicating that system here.

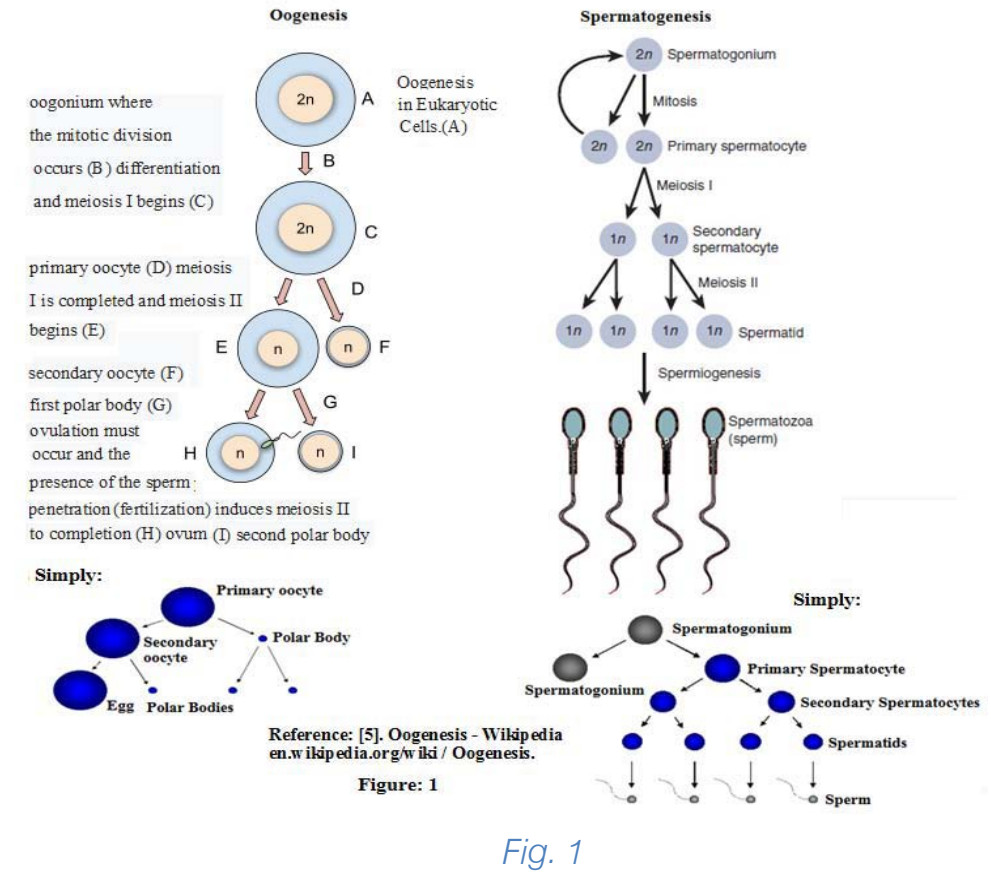

Author: Life Member: 1) Indian Science Congress Association, Kolkata, India. 2) THE VON KARMAN SOCIETY for Advanced Study and Research in Mathematical Sciences (VKS), Old Police line, Jalpaiguri, West Bengal.

Residential Address: MUKUL DEEP, Saratpally, W.No.- 40, 74/48, Meghlal Roy Road by lane. Haiderpara, Siliguri - 734006, Dt: Jalpaiguri, West Bengal (India).e-mail: nirmalgopa@gmail.com 
The coupling system is related to the above birth mechanism. The obtained different numbers are indicating a new era of cell number of how it forms for every life. Why this number almost fixed to the body? How we can determine these numbers in series, which will become apply to the human body and animals. We can treat the number as day, month, hour, second, mile, $\mathrm{km}$, $\mathrm{kg}$, etc where needed. Again the number is the only number may apply to cells as cell number, two bodies coupling periodically. If a couple destroys somehow by the effect of the virus or by any way, the coupling will disturb. As a result, various disease attacks in a body. If we keep coupling steady in a uniform process by medicine or by such equipment, we can protect ourselves.

Let us go through the Couple System a new process:

Application of "No-1 Formation": [1, 2]

Problem (1):

The well known equation $(r+M)^{2}=r^{2}+2 r M+M^{2}$. Similarly, $(r+M)^{3}=r^{3}+3 r\left(r M+M^{2}\right)+M^{3}$. Likewise, $(r+M)^{4},(r+M)^{5},(r+M)^{6}$ etc. but new function derived in the form of:

If $\quad(r+M)^{3} \rightarrow r^{3}+3 r\left(r M+M^{2}\right)+M^{3}$ and let $M=1$, then

$(r+1)^{3} \rightarrow r^{3}+3 r\left(r 1+1^{2}\right)+1^{3} \rightarrow r^{3}+3 r(r+1)+1 \ldots \ldots$. Known fact.

The middle part of the above equation, $3 r(r+1)$ means 3 times of the factor $[r(r+1)]$. Let, $r=A, 1=B$ and $R=(r+1)$. Naturally, $R$ interrelated to $A$ and $B$ shown here in the form of:

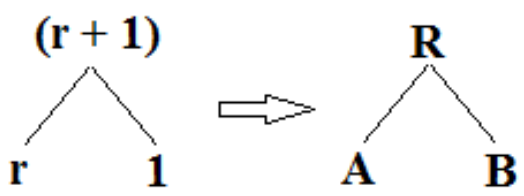

Fig. 2

So, the equation,

$(r+1)^{3}=r^{3}+3 r R+1^{3}$ is representing the equation of $(r+1)^{3} \rightarrow r^{3}+3 r\left(r 1+1^{2}\right)+1^{3} \rightarrow r^{3}+3 r(r+1)+1$ (known).

If the figure 1 is extended as:

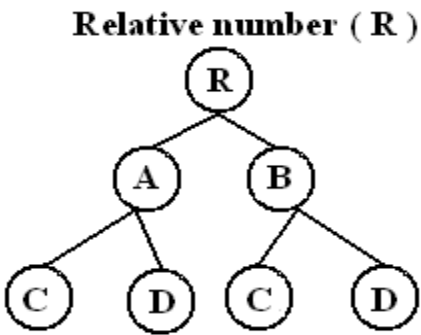

No. 1, Formation

Fig. 2

Reaction of couple:

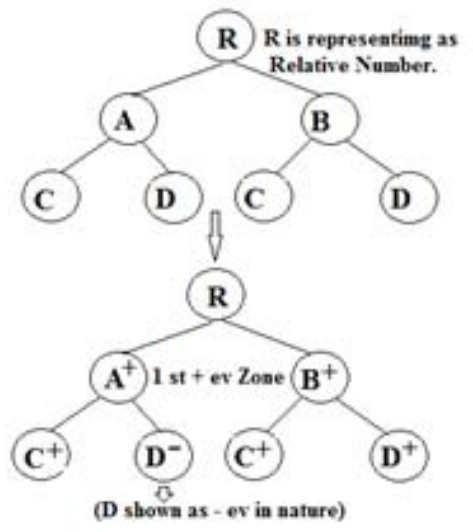

If $\mathrm{A} \& \mathrm{~B}$ takes place in the form of $\mathrm{A}^{+} \& \mathrm{~B}^{+}$in + ev zone and $\mathrm{C} \& \mathrm{D}$ takes place in - ev zone in the form of $\mathrm{D}^{-} \& \mathrm{C}^{+}$related to $\mathrm{A}^{+} \& \mathrm{~B}^{+}$in + ev zone, then we can dressed in the form given bellow:

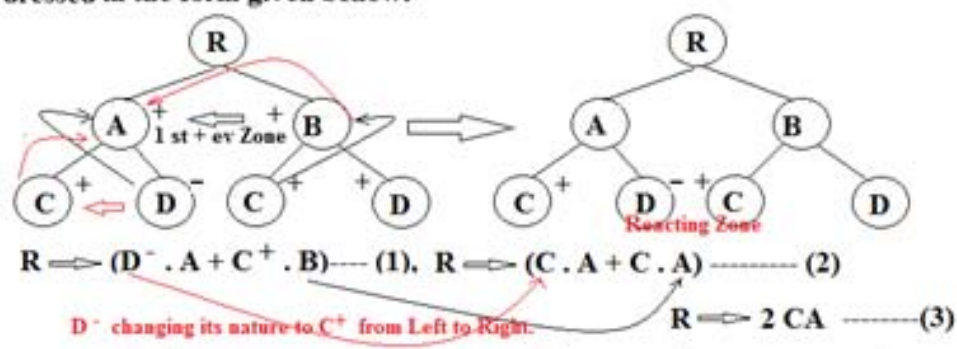

[D related to $\mathrm{C}^{+}, \mathrm{C}+$ related to $\mathrm{A}^{+}$(L.H.S.), agaia $\mathrm{C}^{+}$related to $\mathrm{B}^{+}$(R.H.S.), \& also $\mathrm{B}^{+}$related to $\mathrm{A}^{+}$]

Fig. 3 
Description:

1) $D$ is related to $A$ and $C$ is related to $B$. But $A$ and $C$ are respectively the value of $B$ and $D$. $D^{-}$In L.H.S. means that it is the end of the reaction of problem to form relative number $(R)$ acting with $C^{+}$in R.H.S.

2) The original value of $D$ is $C$; therefore, $D$ reacts with $A$ and forms $C A$. Similarly, $C$ is original value of $D$, but the original value of $B$ is $A$. So, $C$ reacts with $B$ and forms $C A$.

3) Total couple reaction with respect to $R$ is $2 C A$.

No. 2, Formation

When the couple will increase to one step towards E \& F (Fig. - 4) from the coupling zone of C \& D (Fig- 3) respectively, the positive $(+)$ \& negative $(-)$ sign will play as the reverse function of "No. 1 , formation" that is, $F$ to $\mathrm{F}^{+}$ on L.H.S. of the couple \& $E$ to $E^{+}$on R.H.S. of the couple. If $D^{-}$remains unchanged \& $C^{+}$turns to $C^{-}$(1st negative row).

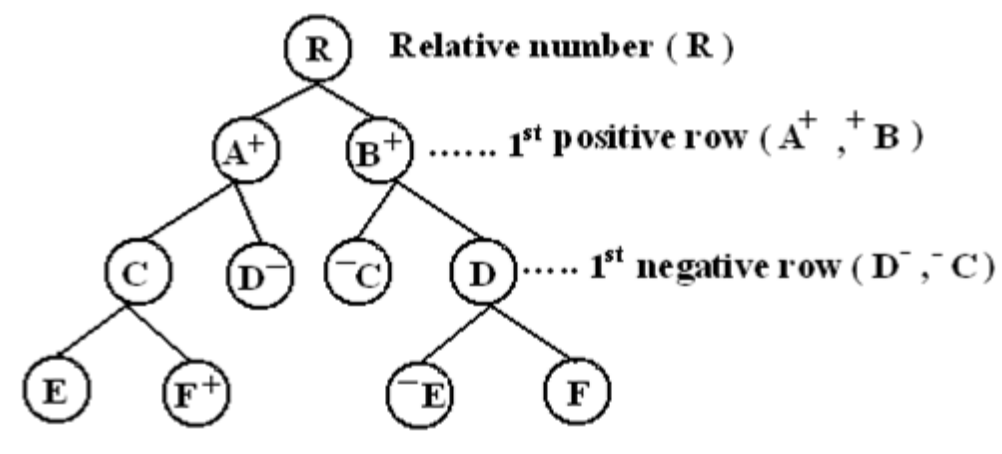

Fig. 4

(No. 2, Formation)

The couple reaction with respect to $\mathrm{R}$ as follows:

$$
\begin{aligned}
& \longrightarrow\left[\mathrm{F}^{\top} \cdot \mathrm{C}+\mathrm{E} \cdot \mathrm{D}\right]+\left[\mathrm{D}^{-} \cdot \mathrm{A}+\mathrm{C} \cdot \mathrm{B}\right] \\
& \cdots[\mathrm{E} \cdot \mathrm{C}+(-\mathrm{E} \cdot-\mathrm{C})]+[\mathrm{C} \cdot \mathrm{A}+(-\mathrm{C} \cdot \mathrm{A})] \\
& \cdots \\
& \cdots-\mathrm{E} \cdot \mathrm{E} \cdot \mathrm{C}+\mathrm{E} \cdot \mathrm{C}]+[\mathrm{C} \cdot \mathrm{A}-\mathrm{C} \cdot \mathrm{A}]
\end{aligned}
$$

Hence: $\mathrm{R} \cdots+2 \mathrm{E} . \mathrm{C}$

When the couple will increase to one more step towards $G$ \& $H$ (Fig.- 5) from the couple zone of E \& F (Fig.- 4) respectively, then the end of the couple will play as a function of "No. 1 formation " and if $\mathrm{F}^{+}$remain unchanged and $\mathrm{E}^{-}$turns to $\mathrm{E}^{+}$, then another positive row will be formed (Fig.- 5). If the couple proceeds to another next step, the end of the couple will follow "No. 2, formation " and again one negative row will be formed (Fig. $5)$.

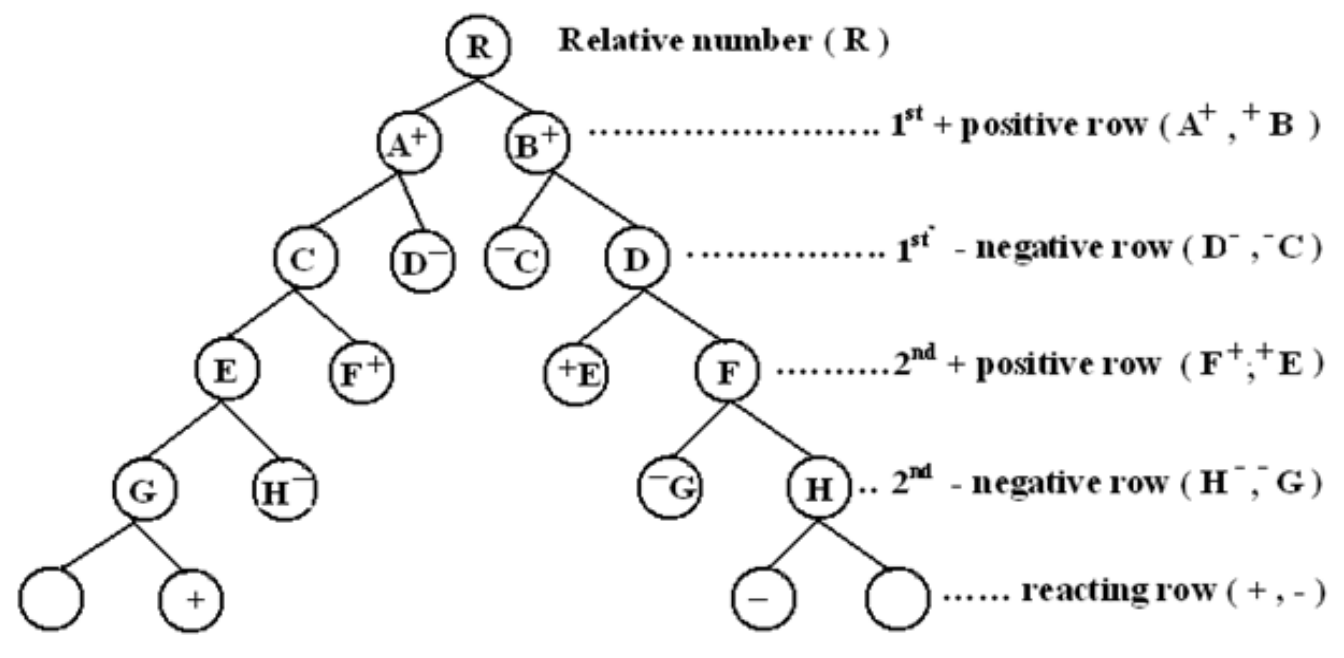

Fig. 5 
If the process continues as above alternately as $+v e,-v e,+v e,-v e,+v e,-v e, \ldots \ldots$. . rows will produced successively and middle part of the couple will be zero after the couple reactions (vide problems). This process is applicable to determination of value of Pi. [1,2]. Wonder Findings of Number of Cells in a Body Including Sexual Cells, Remedy of Corona Virus, Increase of Memory, and Other Cells by Couple System.

To follow the figure -3 ,

Let us an example, $(r+1)^{2}=r^{2}+2 r .1+1^{2}$

Middle term is $2 r .1$ and may represent by R. then according to fig. -3 we can draw a figure as,



$$
\begin{aligned}
& R \Rightarrow 1^{-} . r+r . r \Rightarrow 1^{-} \text {in L.H.S. is representing as } 1 \\
& R \Rightarrow 1 . r+r .1 \Rightarrow \text { and } r \text { as } 1 \text { in R.H.S. } \\
& R \Rightarrow 2 r
\end{aligned}
$$

Fig. 6

The equation $(a+b)^{2},(a+b)^{3},(a+b)^{4},(a+b)^{5}$, etc are very well known simple equation. If we consider middle term of this equation represented by $\mathrm{R}$ and put in coupling system to find relative numbers, then we can get a new series of numbers which may apply to some fields. The obtained new equation is:

$$
(r \pm M)^{N} \rightarrow r^{N} \pm M^{[1+2(N-2)]} \cdot N r \cdot(N-1) r \pm M^{N}
$$

And middle part of this equation is $\mathrm{M}^{[1+2(\mathrm{~N}-2)]}$. Nr. $(\mathrm{N}-1) \mathrm{r}$

The process is given here step by step.

We known the equation $(r+1)^{3}$, it will turns to $(r+1)^{3}=r^{3}+3 r .2 r+1^{3}$ using couple system.

If $M=2,3,4,5, \ldots$. Then, we can get the following series.

$$
\begin{aligned}
& (r+2)^{3} \rightarrow r^{3}+2^{3} \cdot 3 r \cdot 2 r+2^{3} \\
& (r+3)^{3} \rightarrow r^{3}+3^{3} \cdot 3 r \cdot 2 r+3^{3} \\
& (r+4)^{3} \rightarrow r^{3}+4^{3} \cdot 3 r \cdot 2 r+4^{3} \\
& (r+5)^{3} \rightarrow r^{3}+5^{3} \cdot 3 r \cdot 2 r+5^{3} \\
& (r+M)^{3} \rightarrow r^{3}+M^{3} \cdot 3 r \cdot 2 r+M^{3} .
\end{aligned}
$$

This equation (a) will satisfy by only 0 \& 1 .

When, $r$ and $M=0$, then result brings 0 , but, when $r=M=1$, then, on putting this value in L.H.S., $(r+M)^{3}=$ $(1+1)^{3}=2^{3}=8$ and for R.H.S., $r^{3}+M^{3}$.3r. $2 r+M^{3}=1^{3}+1^{3} \cdot(3 \times 1) \cdot(2 \times 1)+1^{3}=1+6+1=8$. This equation satisfying Binary Numbers as 0 \& 1 only. This equation will not satisfy others numbers like 2,3,4, etc, in this case numbers of L.H.S. and R.H.S. will defer, for example, if $r=1 \& M=2$, the we get,

$$
\begin{aligned}
(r+M)^{3} & \rightarrow r^{3}+M^{3} \cdot 3 r \cdot 2 r+M^{3} \\
(1+2)^{3} & \rightarrow 1^{3}+2^{3} \cdot(3 \times 1) \cdot(2 \times 1)+2^{3} \\
27 & \rightarrow 1+8 \times 3 \times 2+8 \\
27 & \rightarrow 57
\end{aligned}
$$

L.H.S is known equation, R.H.S. is unknown.

Here we can say, relative number of 27 is 57 . The difference between is 30 . We considered numbers as 1 \& 2 for $r$ and $M$. Now $1+2=3$, so, $30-3=27$, this similarity we have from this relation using the number $1 \& 2$ only. From the above deduction, we can arrange the equation, $(r+1)^{3}=r^{3}+3 r(r+1)+1$ to $(r+1)^{3} \rightarrow r^{3}+3 r .2 r+1^{3}$ $\rightarrow(r+1)^{3} \rightarrow r^{3}+1^{3} \cdot 3 r \cdot 2 r+1^{3}$. Similarly, on putting next odd number 5 , then, we observed that: 
Problem (2):

When, $(r+M)^{5} \rightarrow r^{5}+5 r\left(r^{3}+2 r^{2}+2 r+1\right)+1^{5}$, then, $R=r^{3}+2 r^{2}+2 r+1$, if $A, B, C$, D represents the corresponding values of $r^{3}, 2 r^{2}, 2 r, 1$ (Since, these are the real values of $\left.(r+1)^{5}\right)$ respectively. Then, $R$ will relate in Couple Systems as follows:

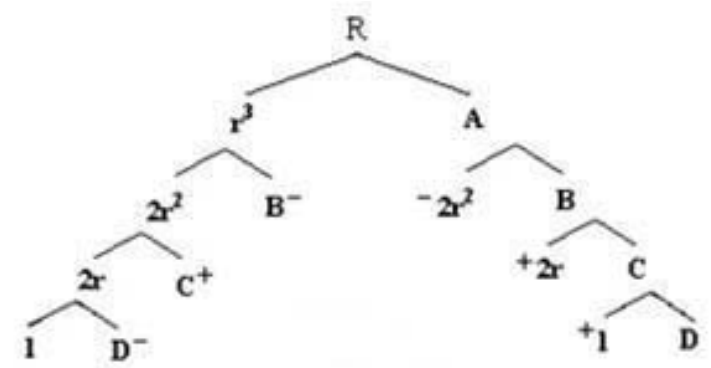

Fig. 7

$$
\begin{aligned}
& R \rightarrow\left(D^{-} .2 r+1 . C\right)+\left(C^{+} .2 r^{2}+2 r^{+} . B\right)+\left(B^{-} .2 r^{3}+2 r^{-2} \cdot A\right) \\
& R \rightarrow(1.2 r+1.2 r)+\left(2 r \cdot 2 r^{2}+2 r \cdot 2 r^{-2}\right)+\left(2 r^{2} \cdot 2 r^{3}+2 r^{-2} \cdot r^{3}\right) \\
& R \rightarrow 1 .(2 r+2 r)+\left(2 r .2 r^{2}-2 r \cdot 2 r^{-2}\right)+\left(2 r^{2} \cdot 2 r^{3}-2 r^{-2} \cdot r^{3}\right) \\
& R \rightarrow 4 r+0+0 \\
& R \rightarrow 4 r
\end{aligned}
$$

Therefore,

$$
(r+1)^{5} \rightarrow r^{5}+5 r \cdot 4 r+1^{5}
$$

If $M=2,3,4,5 \ldots .$. [Vide Problem (1)], then,

$$
\begin{aligned}
& (r+2)^{5} \rightarrow r^{5}+2^{7} .5 r .4 r+1^{5} \\
& (r+3)^{5} \rightarrow r^{5}+3^{7} .5 r .4 r+1^{5} \\
& (r+4)^{5} \rightarrow r^{5}+4^{7} .5 r .4 r+1^{5} \\
& (r+5)^{5} \rightarrow r^{5}+5^{7} .5 r .4 r+1^{5} \\
& \ldots \ldots \ldots \ldots \ldots \ldots \ldots \ldots \ldots \ldots \ldots \ldots \ldots \ldots \ldots \ldots \ldots \\
& (r+M)^{5} \rightarrow r^{5}+M^{7} .5 r .4 r+M^{5}
\end{aligned}
$$

Therefore, the real formation of $(r+1)^{5}$ will $r^{5}+1^{7} .5 r .4 r+1^{5}$

Problem (3):

When, $(r+M)^{7} \rightarrow r^{7}+7 r\left(r^{5}+3 r^{4}+5 r^{3}+5 r^{2}+3 r+1\right)+1^{7}$, then, $R$ will related to bellow as:

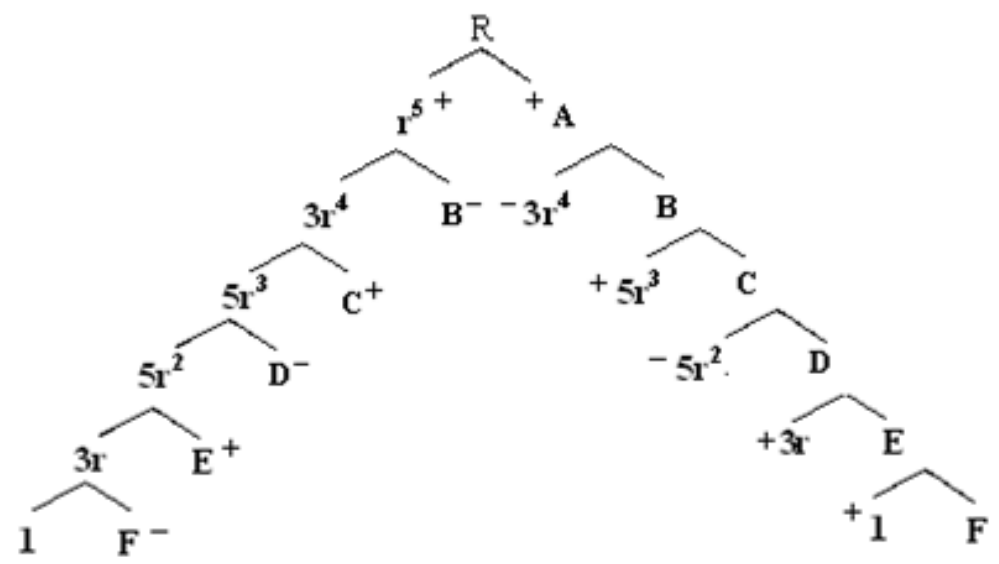

Fig. 8 
$R \rightarrow\left(F^{-} .3 r+1^{+} . E\right)+\left(E^{+} \cdot 5 r^{2}+3 r^{+} . D\right)+\left(D^{-} \cdot 5 r^{3}+5 r^{-2} \cdot C\right)+\left(C^{+} .3 r^{4}+5 r^{+3} \cdot B\right)+\left(B^{-} \cdot r^{5}+3 r^{-} \cdot A\right)$

$R \rightarrow(1.3 r+1.3 r)+\left(3 r \cdot 5 r^{2}+3 r \cdot 5 r^{-2}\right)+\left(5 r^{2} \cdot 5 r^{3}+5 r^{-2} \cdot 5 r^{3}\right)+\left(5 r^{3} \cdot 3 r^{4}+5 r^{3} \cdot 3 r^{-4}\right)+\left(3 r^{4} \cdot r^{5}+3 r^{-4} \cdot r^{5}\right)$

$R \rightarrow(1.3 r+1.3 r)+0+0+0+0=1 .(3 r+3 r)=1 \times 6 r=6 r$.

$(r+1)^{7} \rightarrow r^{7}+1^{7} \cdot 7 r \cdot 6 r+1^{7}$ and if $M=2,3,4,5 \ldots .$, then,

$$
\begin{aligned}
& (r+2)^{7} \rightarrow r^{7}+2^{11} \cdot 7 r \cdot 6 r+2^{7} \\
& (r+3)^{7} \rightarrow r^{7}+3^{11} \cdot 7 r \cdot 6 r+3^{7} \\
& (r+4)^{7} \rightarrow r^{7}+4^{11} \cdot 7 r \cdot 6 r+4^{7} \\
& (r+5)^{7} \rightarrow r^{7}+5^{11} \cdot 7 r \cdot 6 r+5^{7}
\end{aligned}
$$

$$
(r+M)^{7} \rightarrow r^{7}+M^{11} \cdot 7 r \cdot 6 r+M^{7}
$$

"No - 1 formation" is only for the series of odd numbers as $1,2,3,5 \ldots$.., if the series increases, then the process of couple will increase.

Application of "No - 2 formation" for even number. [1]

Problem (1):

$(r+1)^{4} \rightarrow r^{4}+4 r \cdot\left(r^{2}+[3 / 2] \times r+1\right)+1^{4}=r^{4}+4 r .(R)+1^{4}$

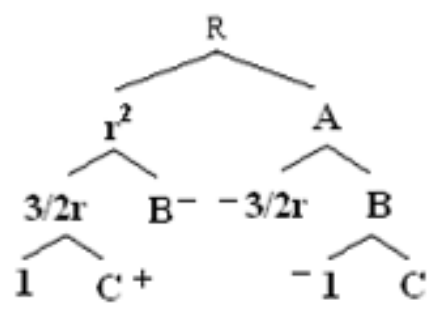

Fig. 9

$R \rightarrow\left(C .[3 / 2] \times r+1^{-} . B\right)+\left(B^{-} \cdot r^{2}+[3 / 2] \times r^{-} . A\right)$

$R \rightarrow\left(1 .[3 / 2] \times r+1^{-} \cdot[3 / 2] \times r^{-}\right)+\left([3 / 2] \times r . r^{2}+[3 / 2] \times r^{-} . r^{2}\right)$

$R \rightarrow 2 \cdot[3 / 2] \times r+0=3 r$

Note:

$(a+b)^{4}=a^{4}+4 a^{3} b+6 a^{2} b^{2}+4 a b^{3}+b^{3}=a^{4}+2 a b\left(2 a^{2}+3 a b+2 b^{2}\right)+b^{4}$.

$=a^{4}+4 a b\left(a^{2}+[3 / 2] \times a b+b^{2}\right)+b^{4}$, when $b=1$, then,

$(a+1)^{4}=a^{4}+4 a .1\left(a^{2}+[3 / 2] \times a .1+1^{2}\right)+1^{4}=a^{4}+4 a\left(a^{2}+[3 / 2] \times a+1^{2}\right)+1^{4}$, when, $a=r$, then, $(r+1)^{4}=$ $r^{4}+4 r\left(r^{2}+[3 / 2] \times r+1^{2}\right)+1^{4}=$ Let, $R=\left(r^{2}+[3 / 2] \times r+1^{2}\right)$ and so,

$(r+1)^{4} \rightarrow r^{4}+4 r .(R)+1^{4} \rightarrow r^{4}+4 r .([3 / 2] \times r)+1^{4}$ and $R \rightarrow[3 / 2] \times r=3 \cdot r=3 r$. Now we can get a series in the forms of: $(r+1)^{4} \rightarrow r^{4}+1^{5} \cdot 4 r \cdot 3 r+1^{4}$

Similarly,

$$
\begin{aligned}
& (r+2)^{4} \rightarrow r^{4}+2^{5} \cdot 4 r \cdot 3 r+2^{4} \\
& (r+3)^{4} \rightarrow r^{4}+3^{5} \cdot 4 r \cdot 3 r+3^{4} \\
& (r+4)^{4} \rightarrow r^{4}+4^{5} \cdot 4 r \cdot 3 r+4^{4} \\
& (r+5)^{4} \rightarrow r^{4}+5^{5} \cdot 4 r \cdot 3 r+5^{4}
\end{aligned}
$$

$(r+M)^{4} \rightarrow r^{4}+M^{5} \cdot 4 r \cdot 3 r+M^{4}$

For power 6, we get,

$$
(r+1)^{6} \rightarrow r^{6}+1^{9} \cdot 6 r \cdot 5 r+1^{6}
$$




$$
\begin{aligned}
& (r+2)^{6} \rightarrow r^{6}+2^{9} \cdot 6 r \cdot 5 r+2^{6} \\
& (r+3)^{6} \rightarrow r^{6}+3^{9} \cdot 6 r \cdot 5 r+3^{6} \\
& \ldots \ldots \ldots \ldots \ldots \ldots \ldots \ldots \ldots \ldots \ldots \ldots \ldots \ldots \ldots \ldots \ldots \\
& (r+M)^{6} \rightarrow r^{6}+M^{9} \cdot 6 r \cdot 5 r+M^{6}
\end{aligned}
$$

"No - 2, formation" is only for the series of powers of $(r+M)$, when integrates acts as a function of, 2,4,6,8 .... When the series increases, then the process of couple increases.

Hence the series:

$$
\begin{gathered}
(r+M)^{2} \rightarrow r^{2}+M^{1} \cdot 2 r \cdot 1 r+M^{2} \\
(r+M)^{3} \rightarrow r^{3}+M^{3} \cdot 3 r \cdot 2 r+M^{3} \\
(r+M)^{4} \rightarrow r^{4}+M^{5} \cdot 4 r \cdot 3 r+M^{4} \\
(r+M)^{5} \rightarrow r^{5}+M^{9} \cdot 5 r \cdot 4 r+M^{5} \\
(r+M)^{6} \rightarrow r^{6}+M^{9} \cdot 6 r \cdot 5 r+M^{6} \\
(r+M)^{7} \rightarrow r^{7}+M^{11} \cdot 7 r \cdot 6 r+M^{7} \\
\quad(r+M)^{N} \rightarrow r^{N}+M^{[1+2(N-2)]} \cdot N r \cdot(N-1) r+M^{N} \ldots \ldots \ldots \ldots \ldots \ldots \ldots \ldots \\
(r+M)^{N} \rightarrow r^{N}+M^{2} . N r \cdot(N-1) r+M^{N} \ldots \ldots
\end{gathered}
$$

When, $Z=[1+2(\mathrm{~N}-2)] \& N=2,3.4 \ldots \ldots$

In the case of negative functions, this equation will turn to:

$$
\begin{aligned}
& (r-M)^{N} \rightarrow r^{N}-M^{[1+2(N-2)]} \cdot N r .(N-1) r-M^{N} \\
& \quad(r-M)^{N} \rightarrow r^{N}-M^{Z} \cdot N r .(N-1) r-M^{N} \ldots \ldots \ldots
\end{aligned}
$$

Relative Numbers (R):

The middle part of the equation $(A)$ or $(B)$ and $(C)$ or $(D)$ is same. We have the Relative number as [Nr. $(\mathrm{N}$ 1)r] which connected to $M^{[1+2(N-2)]}$ or $M^{Z}$, when $Z=[1+2(N-2)]$ of $(r+M)^{N}$ or $(r-M)^{N}$. so, we may write the general equation in the form of:

$$
(r \pm M)^{N} \rightarrow r^{N} \pm M^{[1+2(N-2)]} \cdot N r .(N-1) r \pm M^{N}
$$

And middle part of this equation is

$$
\mathrm{M}^{[1+2(\mathrm{~N}-2)]} \cdot \mathrm{Nr} .(\mathrm{N}-1) \mathrm{r}
$$

When, $N=1,2,3,4,5 \ldots$ we get relative numbers $1 r, 2 r, 3 r, 4 r, 5 r$ etc both of even and odd numbers. The equation (A) obtained by the couple system and is applicable in forming relative numbers with respect to $Z$ of which numbers become odd in series, when $N=2,3,4,5 \ldots$ of the equation, $M^{[1+2(N-2)]} . N r$. $(N-1) r$. On changing the number of $Z$ as $Z=[2+2(N-2)]$, we get,

$$
\mathrm{M}^{[2+2(\mathrm{~N}-2)]} \cdot \mathrm{Nr} .(\mathrm{N}-1) \mathrm{r} \rightarrow \mathrm{M}^{2} .2 \mathrm{r} \cdot 1 \mathrm{r} \text {, when } \mathrm{N}=2
$$

$M^{[2+2(N-2)]}$.Nr. $(N-1) r \rightarrow M^{4}$. 3r.2r, when $N=3$, where, $(r+M)^{3} \rightarrow M^{3}$.3r.2r, when, $N=3$, due to change of $Z$, power changes as:

When, $Z=[1+2(\mathrm{~N}-2)], Z=-3$, when, $N=0$ (not satisfying).

$Z=[1+2(N-2)], Z=-1$, when, $N=1$ (not satisfying).

$Z=[1+2(N-2)], Z=1$, when, $N=2$ (satisfying). It shows $N>1$

If, $Z=[2+2(\mathrm{~N}-2)]$, we get,

$Z=[2+2(N-2)], Z=-2$, when, $N=0$ (not satisfying)

$Z=[2+2(N-2)], Z=0$, when, $N=1$ (satisfying), because, $M^{Z}=M^{0}=1$

$Z=[2+2(N-2)], Z=2$, when, $N=2$ (satisfying), $N>1$ 
At the time of changing of $\mathrm{Z}$, let, $\mathrm{Nr}$. $(\mathrm{N}-1) \mathrm{r}$ will change to $\mathrm{Nr}$. $(\mathrm{N}-2)$, then, we get a series as:

$$
\begin{aligned}
& M^{[2+2(N-2)]} \cdot N r .(N-2) r \rightarrow M^{0} .0 \times r \cdot(0-2) r=0 \text {, when } N=0 \\
& M^{[2+2(N-2)]} \cdot N r .(N-2) r \rightarrow M^{-1} .1 r \cdot(1-2) r=M^{-1} \times 1 r \times-1=-M^{-1} \quad \text { when } N=1 \\
& M^{[2+2(N-2)]} \cdot N r .(N-2) r \rightarrow M^{2} .2 r \cdot 0 \times r=0, \text { when } N=2 \\
& M^{[2+2(N-2)]} \cdot N r .(N-2) r \rightarrow M^{4} .3 r .1 r \text {, when } N=3 \text { etc., } N>2
\end{aligned}
$$

When this equation turns to $\mathrm{M}^{[2+2(\mathrm{~N}-2)]}$. Nr. $\mathrm{Nr} \ldots \ldots(\mathrm{G})$, when, $(\mathrm{N}-1) \mathrm{r}$ treated as $\mathrm{Nr}$, then we will get even numbers (Z) of $\mathrm{M}$ of the series. So,

$M^{[2+2(N-2)]} \cdot N r \cdot N r \rightarrow M^{2} \cdot 2 r \cdot 2 r$, when, $N=2, N>1$, if, $M=r=1, M^{2} \cdot 2 r \cdot 2 r=400 \& 400 / 2=200$.

$$
\begin{aligned}
& M^{[2+2(N-2)]} \cdot N r . N r \rightarrow M^{4} .3 r .3 r \text {, when, } N=3 \\
& M^{[2+2(N-2)]} \cdot N r . N r \rightarrow M^{6} .4 r .4 r \text {, when, } N=4 \text { etc. }
\end{aligned}
$$

Therefore, the deduction $(F)$ and $(G)$ finds,

$$
\begin{aligned}
& M^{[1+2(N-2)]} . N r .(N-1) r \rightarrow M^{1} .2 r .1 r \text {, when, } N=2, Z=1 \text { of power of } M \text {, odd number. } \\
& M^{[2+2(N-2)]} . N r . N r \rightarrow M^{2} .2 r .2 r \text {, when, } N=2, Z=2 \text { of power of } M \text {, even number. } \\
& M^{[1+2(N-2)]} . N r .(N-1) r \rightarrow M^{3} \text {.3r.2r, when, } N=3, Z=3 \text { of power of } M \text {, odd number. } \\
& M^{[2+2(N-2)]} . N r . N r \rightarrow M^{4} .3 r .3 r \text {, when, } N=3, Z=4 \text { of power of } M \text {, even number. }
\end{aligned}
$$

From the above deduction, we have the following results as:

i) When, $N=0$, the equation $(F)$ yields $M^{-3} \cdot$ Or. $(-1) \cdot r$
ii) $" \quad \mathrm{~N}=0$,
(G)
$\mathrm{M}^{-2}$.Or.Or
iii) $" \quad N=1$,
(F) $\quad " \quad M^{-1} \cdot 1 r \cdot 0 r$
iv) $" \quad N=1$,
(G) $\quad " M^{0} .1 r .1 r$

Therefore, when $N$ has tendency to proceed in negative direction, i.e, $N=-1,-2,-3,-4 \ldots .$. then the deduction $(F) \&(G)$ will give results, the yielded values are listed here in a table $(\mathrm{Zr})$.

Relative Numbers obtained by Couple System.

Table (Zr):

$$
M^{z} \times\left[\begin{array}{lllllll}
r_{2} & x & r_{1}
\end{array}\right] \quad M^{-z}\left[\begin{array}{llll}
x & -r_{2}^{\prime} & x & -r_{1}^{\prime}
\end{array}\right]
$$

R.H.S.(Relative No.) (Relative No.) L.H.S.

$$
\begin{aligned}
& M^{0} \times 1 \times 1=1\left(M^{0}=1^{0}=1 \text {, when, } M=1 \text { and relative number, } 1 \times 1=1\right. \\
& M^{1} \times 2 \times 1 \quad M^{-1} \times 1 \times 0 \quad \text { Now, } 2 / 0=2
\end{aligned}
$$

[Relative number $\left.=2\left(r_{2}\right) \times 1\left(r_{1}\right)=2 \times 1=2\right]$. On the other hand,

$\left(1^{1} \times 2 \times 1=10 \times 2 \times 1=20\right.$ and $20 / 10=2$, and $1^{-1} \times 1 \times 0=0.1 \times 1 \times 0=0$. so, $\left.2 / 0=2\right)$.

$$
\begin{array}{lllllllllll}
M^{2} & \times & 2 & \times & 2 & M^{-2} & \times & 0 & \times & 0 & \text { Now, } 4 / 0=4 \\
M^{3} \times & \times & \times & 2 & M^{-3} & \times & 0 & \times & -1 & \text { Now, } 6 / 0=6 \\
M^{4} \times & \times & \times & 3 & M^{-4} & \times & -1 & \times & -1 & \text { Now, } 9 / 1=9 \\
M^{5} & \times & 4 & \times & 3 & M^{-5} & \times & -1 & \times & -2 & \text { Now, } 12 / 2=6 \\
M^{6} & \times & 4 & \times & 4 & M^{-6} & \times & -2 & \times & -2 & \text { Now, } 16 / 4=4 \\
M^{7} \times & \times & \times & \times & M^{-7} & \times & -2 & \times & -3 & \text { Now, 20/6=3.333 } \\
M^{8} \times & 5 & \times & 5 & M^{-8} & \times & -3 & \times & -3 & \text { Now, 25/9=2.777 } \\
M^{9} \times & 6 & \times & 5 & M^{-9} & \times & -3 & \times & -4 & \text { Now, 30/12 = 2.5 }
\end{array}
$$




$$
\begin{aligned}
& M^{10} \times 6 \times 6 \quad M^{-10} \times \quad-4 \times \quad \times \quad-4 \quad \text { Now, 36/16 }=2.25 \\
& M^{11} \times 7 \times 6 \quad M^{-11} \times \quad-4 \times \quad-5 \quad \text { Now, } 42 / 20=2.1 \\
& M^{12} \times 7 \times 7 \quad M^{-12} \times \quad-5 \times 1 \times \quad-5 \quad \text { Now, 49/25 = } 1.96
\end{aligned}
$$

up to $n$ numbers, but not to infinity.

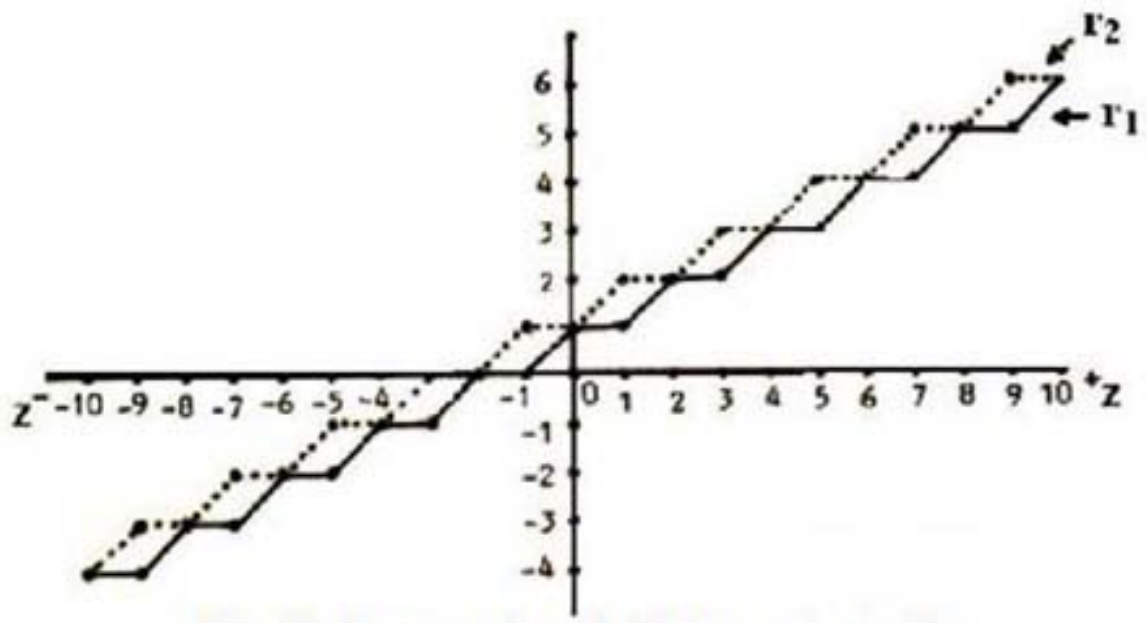

Graphical presentation of relative number $r_{2} \& r_{1}$.

Fig. 10

When the coupling zones presented by +1 in the form of object \& image, then it may treat as $1^{\text {st }}, 2^{\text {nd }}, 3^{\text {rd }}, 4^{\text {th }}$ coupling zones are shown in fig-11.

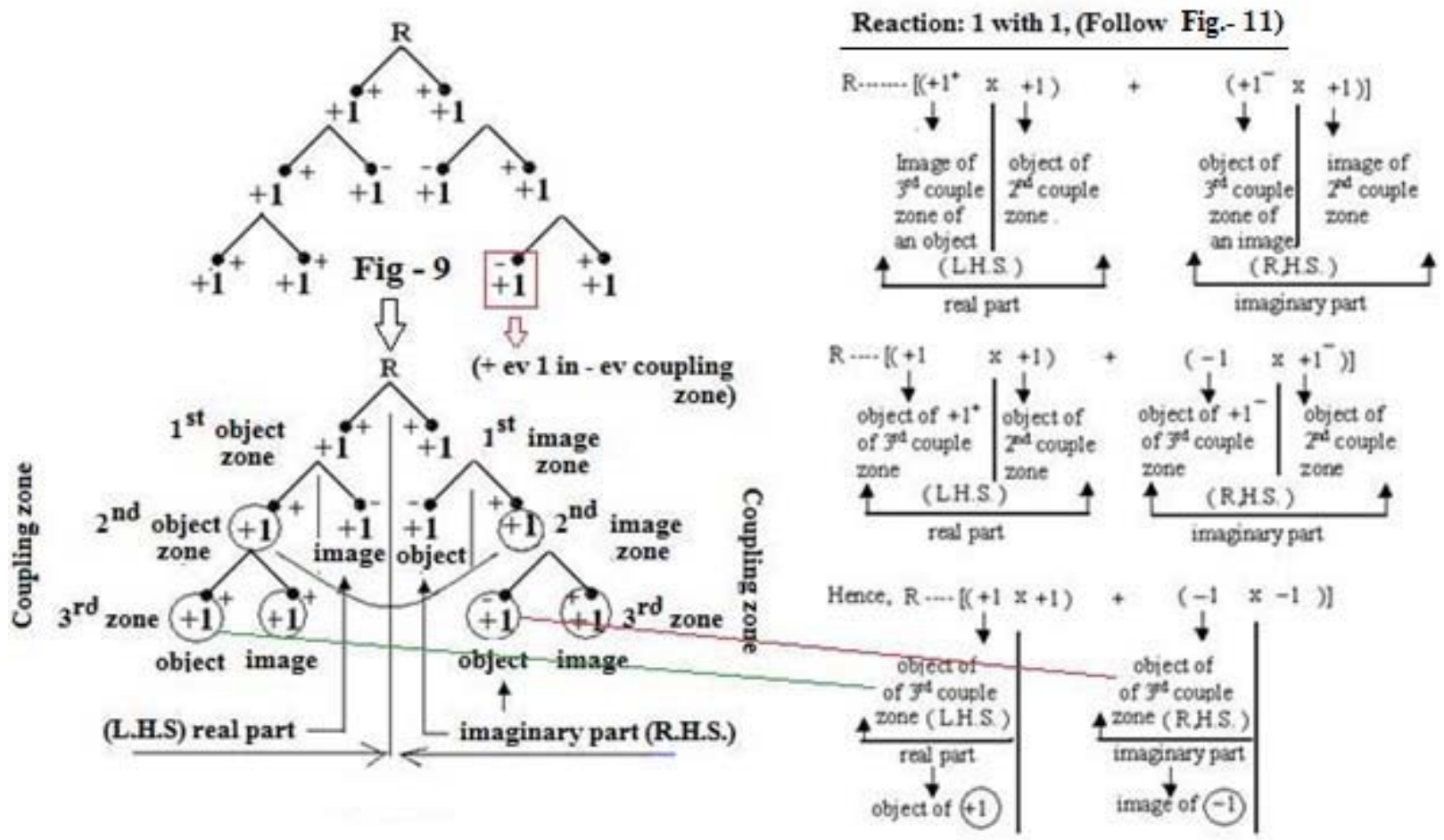

Fig. 11

In this way, if coupling series increases with respect to 1 , the reacting results to be 2 .

This is also applicable to No. 1, Formation. The sum of Fig.-11 is given below for example:

$$
\begin{aligned}
& R \text {---- }\left[\left(+1^{+} x+1\right)+\left(+1^{-} x+1\right)\right]+\left[\left(+1^{-} x+1^{+}\right)+\left(+1^{-} x+1^{+}\right)\right] \\
& R----\left[(+1 x 1)+\left(-1 x+1^{-}\right)\right]+\left[\left(+1 x+1^{+}\right)+\left(-1 x+1^{+}\right)\right]
\end{aligned}
$$




$$
\begin{aligned}
& R \text {----- }[(1 \times 1)+(-1 \times-1)]+[(1 \times 1)+(-1 \times+1)] \\
& R----[(1)+(+1)]+[(1)+(-1)] \\
& R \text {----- }[(2)]+[(1-1)]=2+0=2
\end{aligned}
$$

These formations of relative numbers are most important to find the different types of cells of the brain and other parts of a body. R.H.S. of these formations brings the total number of cells, if we consider $\mathrm{M}$ as base1, that is (According to Calculator, $1^{\wedge} \mathrm{EXP}-0=1$, \& same is applies to all $\mathrm{M}^{\mathrm{n}}$, where, $\mathrm{n}=0,1,2,3,4,5, \ldots \ldots$ ). $\mathrm{M}^{0} \times 1 \times 1=1^{0}$ $x 1 \times 1=1$ number $\left(1^{0}=1\right)$, here we can assume, $1^{0} \times X \times Y=1$ sex cell for male and for female $1^{0} \times X \times X=1$ sex cell. Ten is representing as the relation between two as $1^{0}=1$, which one is commending as love or agrees to meet in sexual functions.

\section{Applications of most basic formation Application:}

Sex cells and chromosomes:

$\mathrm{M}^{1} \times 2 \times 1=1^{1} \times 2 \times 1=20$ numbers $\left(1^{1}=10\right)$ and so on. Here we observed that coefficient of $\mathrm{M}^{1}$ is $2 \& 1$ as relative number and if we add $2+1=3 \& 3$ to $20=23$ numbers. We may treat these 23 numbers as sex cells and $23+23$

$=46$ of human body.

Sex cells and chromosomes [6]

Human body cells each contain 23 pairs of chromosomes. Parents pass on their genes to their offspring in their sex cells. Female sex cells are called egg cells or ova. Male sex cells are called sperm.

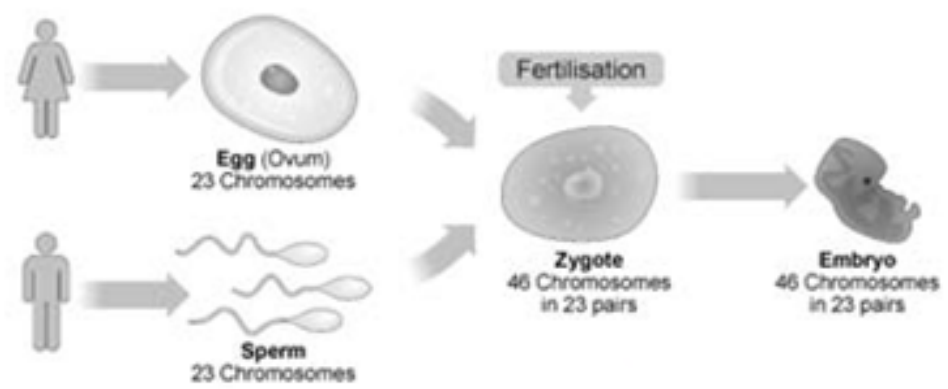

Fig. 12

\section{Process of fertilization:}

Sex cells only contain one chromosome from each pair. When an egg cell and sperm cell join together, the fertilized egg cell contains 23 pairs of chromosomes. One chromosome in each pair comes from the mother, the other from the father.

The pair of chromosome is random. Due to this different child in the same family gets a different combination. This is why children in the same family look a little like each other and a little like each parent but are not identical to them.

Again, $\left[M^{2} \times 2 \times 2\right]=\left[1^{2} \times 2 \times 2=10 \times 2 \times 2=400\right.$, when $\left.M=1\right] .1 / 10$ th of 400 are 40 numbers, If we consider, the coefficient of $\mathrm{M}^{1}$ is 2 and 2 , then, $2+2=4$. Then, $40+4=44$. Then, $44 / 2=22$ cells plus with 1 chromosome, then brings 23 cells. But 44 cells +2 chromosomes $=46$ cells of $X X$ and $X Y$ sex cells.

$$
\text { Again, ratio of } \frac{\left[M^{2} \times 2 \times 2\right] / 10=\left[1^{2} \times 2 \times 2\right] / 10}{M^{I} \times 2 \times 1=1^{I} \times 2 \times 1}=\frac{40}{20}=2
$$

Here, 2 (two) means for any birth, two couples need to meet together.

Birth of Baby:

When power of $M$ increases 1 to 6 , then the equation, $M^{6} \times 4 \times 4=1^{6} \times 4 \times 4=16000000=1.6 \times 10^{7}=16$ million and if we treated as seconds this number, then, $16000000 \mathrm{sec}=185.185$ days or 6.17 months. As so, 6 month baby is unmeasured. If we multiply by the factor $3 / 2,(j=1+1 / 2 \& j=3$, in the case of atomic stage, $j$ used as angular quantum number) then, $16000000 \mathrm{sec} \times(3 / 2)$, then we see that 24 million seconds $=9.26$ months $=9.3$ months. 
If $2 \times\left[\mathrm{M}^{1} \times 2 \times 1\right]=2 \times\left[1^{1} \times 2 \times 1\right]=40$ numbers and if we treated as weeks days, then, "Average human baby pregnancy time vs. other mammals. In general, the larger the animal, the longer the gestation period. In general, the larger the animal, the longer the life.

Human body* 266 days ( 40 weeks $=280$ days) ${ }^{*}$

$\star=280$ days, from the first day of a woman's last menstrual period.

$=266$ days, if measured from the sperm joining the ovum" [7].

40 week days $=9.33$ months, this value is tallied to 9.3 months followed by the equation $(3 / 2) \times M^{6} \times 4 \times 4=1^{6} \times 4 \times$ $4=9.26$ months or 277.8 days. Or $\left[\mathrm{M}^{2} \times 2 \times 2\right] /(3 / 2)=266.66$ days. Therefore, Couple System and obtained relative numbers are most important in the case of birth cells.

We can give other examples from another animal also.

Average Gestation Period Of Different Animals [8]

\begin{tabular}{|c|c|c|}
\hline Animal & & Period (months) \\
\hline African elephant & ant $\begin{array}{l}22(A \\
=44\end{array}$ & $\begin{array}{l}\text { gain, } M^{1} \times 2 \times 2=1^{2} \times 2 \times 2=40 \text { numbers, its coefficient is } 2 \text {, then, } 2+2=4 \text {, so, } 40+ \\
\text { hen, } 44 / 2=22 \text {. May use as } 22 \text { months.) }\end{array}$ \\
\hline Giraffe & 15.25 & (Now $22 / \sqrt{ } 2=15.55$ may use as 15.55 months.) \\
\hline $\begin{array}{l}\text { Humpback } \\
\text { whale }\end{array}$ & $\begin{array}{l}10 \text { to } 1 \\
360 \text { da }\end{array}$ & $\begin{array}{l}2 \quad(22 / 2=11 \text { average period, } 11 \text { months }) \\
\text { ys or } 12 \text { months. }\left[M^{2} \times 2 \times 2\right] / \sqrt{ }(\sqrt{ } 3 / 2)=361.44 \text { days }=12.04 \text { months. }\end{array}$ \\
\hline Bison (buffalo) & 9.5 & $(22 / \sqrt{ } 5=9.83$ months $)$ \\
\hline Human & 9 & $(22 / \sqrt{ } 6=8.98$ months $)$ \\
\hline Hippopotamus & 8 & $(22 / \sqrt{ } 7=8.31$ months $)$ \\
\hline Grizzly bear & 7 & $(22 / \sqrt{ } 10=6.957$ months $)$ \\
\hline Baboon & 5 to 6 & $(22 / \sqrt{ } 14=5.88$ months or $22 / \sqrt{ } 18=5.18$ months $)$ \\
\hline Giant panda & 4 to 5 & $(22 / / \sqrt{ } 20=4.92$ months or $22 / \sqrt{ } 30=4.01$ months $)$ \\
\hline Jaguar & 3.5 & $(22 / \sqrt{ } 40=3.48$ months $)$ \\
\hline Dog & 2 & (22/11 = 2 months) \\
\hline Cat & 2 & (22/11 = 2 months) \\
\hline $\begin{array}{l}\text { Rabbit } \\
\text { Hamster } \\
\text { Lion }\end{array}$ & $\begin{array}{l}1.33 \\
0.5 \text { to } 1 \\
108 \text { days }\end{array}$ & $\begin{array}{l}(22 / 16=1.37 \text { months }) \\
(22 / 44=0.5 \text { or } 22 / 22=1 \text { month }) \\
(22 \text { days } x 5=110 \text { days }=3.66 \text { months })[7]\end{array}$ \\
\hline \multicolumn{3}{|c|}{ Ant 8 to 12 weeks $(22$ days $\times 2 \times \sqrt{ }(3 / 2=53.88=7.698$ weeks $\& 22 \times 4=88=12.57$ weeks $)$} \\
\hline \multicolumn{3}{|c|}{ Camel $=400$ days $=\left[\mathrm{M}^{2} \times 2 \times 2\right]=400$ days or 13.33 months. [7] } \\
\hline \multicolumn{3}{|c|}{ Rhino, Gray $=485$ days equivalent to $\left[\mathrm{M}^{2} \times 2 \times 2\right] \times \sqrt{3} / 2=489.89$ days $=16.329$ months. [7] } \\
\hline \multicolumn{3}{|c|}{ Elephant, Asian $=610$ days equivalent to $400 \times(3 / 2)=600$ days $=20$ months. [7] } \\
\hline \multicolumn{3}{|c|}{ Likewise, we can estimate the period of other animals. } \\
\hline
\end{tabular}

Breaking of couple system (for example cancer cell):

What is cancer?

Cancer is the name given to a collection of related diseases. In all types of cancer, some of the body's cells begin to divide without stopping and spread into surrounding tissues. Cancer can start almost anywhere in the human body, which is buildup of trillions of cells. Human cells grow and divide to form new cells as the body needs them. When cells grow old or become damaged, they die, and new cells take their place. When cancer develops, this orderly process breaks down. As cells become more and more abnormal, old or damaged cells survive when they should die, and new cells form when they are not needed. These extra cells can divide without stopping and may form growths called tumors.

Many cancers form solid tumors, which are masses of tissue of the blood, such as leukemias, generally do not form solid tumors. Cancerous tumors are malignant, which means they can spread into or invade nearby tissues. Also as these tumors grow, some cancer cells can break off and travel to distant places in the body through the blood or the lymph system and form new tumors far from the original tumor. Unlike malignant tumors, benign tumors 
do not spread into or invade nearby tissues. Benign tumors can sometimes be quite large, however. When removed, they usually don't grow back, whereas malignant tumors sometimes do. Unlike most benign tumors elsewhere in the body, benign brain tumors can be life-threatening.

\section{Differences between Cancer Cells and Normal Cells}

Cancer cells differ from cells in many ways that allow them to grow out of control and become invasive. The difference is that cancer cells are less specialized than normal cells. That is, whereas cells mature into very distinct cell types with specific functions, cancer cells do not. This is one reason that, cancer cells continue to divide without stopping [9]. So, without the coupling of two cells, it is never possible to give birth to a new generation. When the virus attracts in a body, then the system of a couple feels disturbed, and as a result, it cannot functioned smoothly. The living body feels trouble called diseases. Cancer is one example in this case. These cells do not follow the couple system in the long run; it breaks haphazardly and destroys other connected cells. A figure is given here, for example.



This colored scanning electron micrograph (SEM) Cell shows undergoing programmed Cell death or apoptosis. [10].

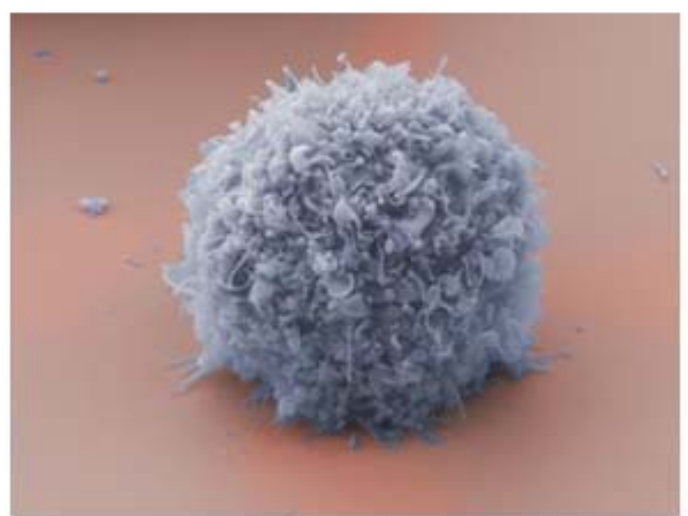

Human Breast Cancer Cell

Fig. 13

In these figures (13), we see that individual cancer cell have no clear hand to proceed in front, but the cell attack to cell and then progress in couple system by damaging each cell. According to reference [11], a figure is given here that how cancer cells dangerous for the body.

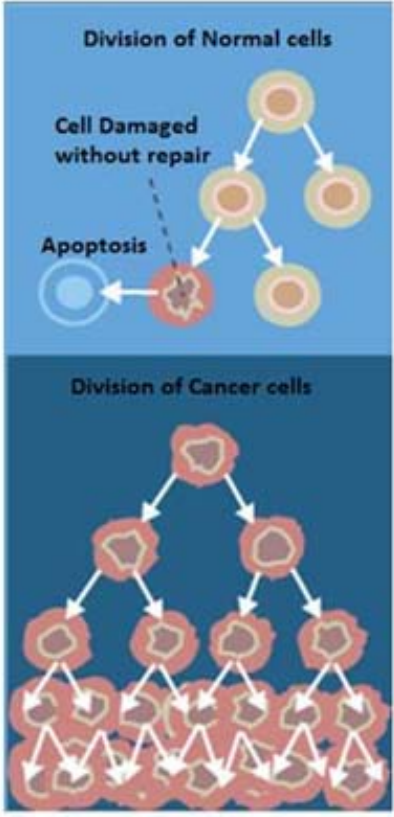

Figure from reference.

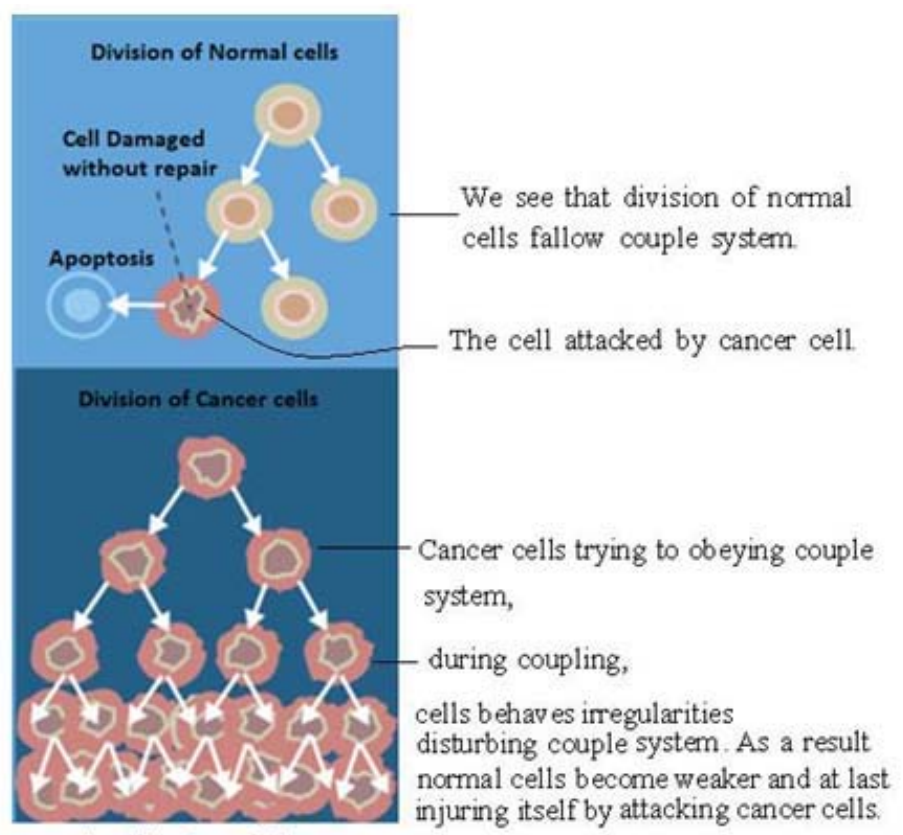

Classification of figure

Fig. 14 
Therefore to fit a body, this is very important that the coupling reaction needs to keep steady by doing exercise. Regular exercise has roll to run coupling cells in every corner of a body and needs balanced food to fit. When the strength of the virus $>$ the strength of coupling, then the virus acts on the body. The same number of cell attacks by the same number of the virus; this is one of the main properties of all cells reaction in the living body. If it is possible to stop growing cancer cells, no entry of cancer cells to the couple system by hook or kook; it is required by adding such medicine or rearranging cells by coupling system in this field to stop the activity of cancer cells. Here is the touch of couple system that how it is important in cell properties.

The probable cause of breaking of cells:
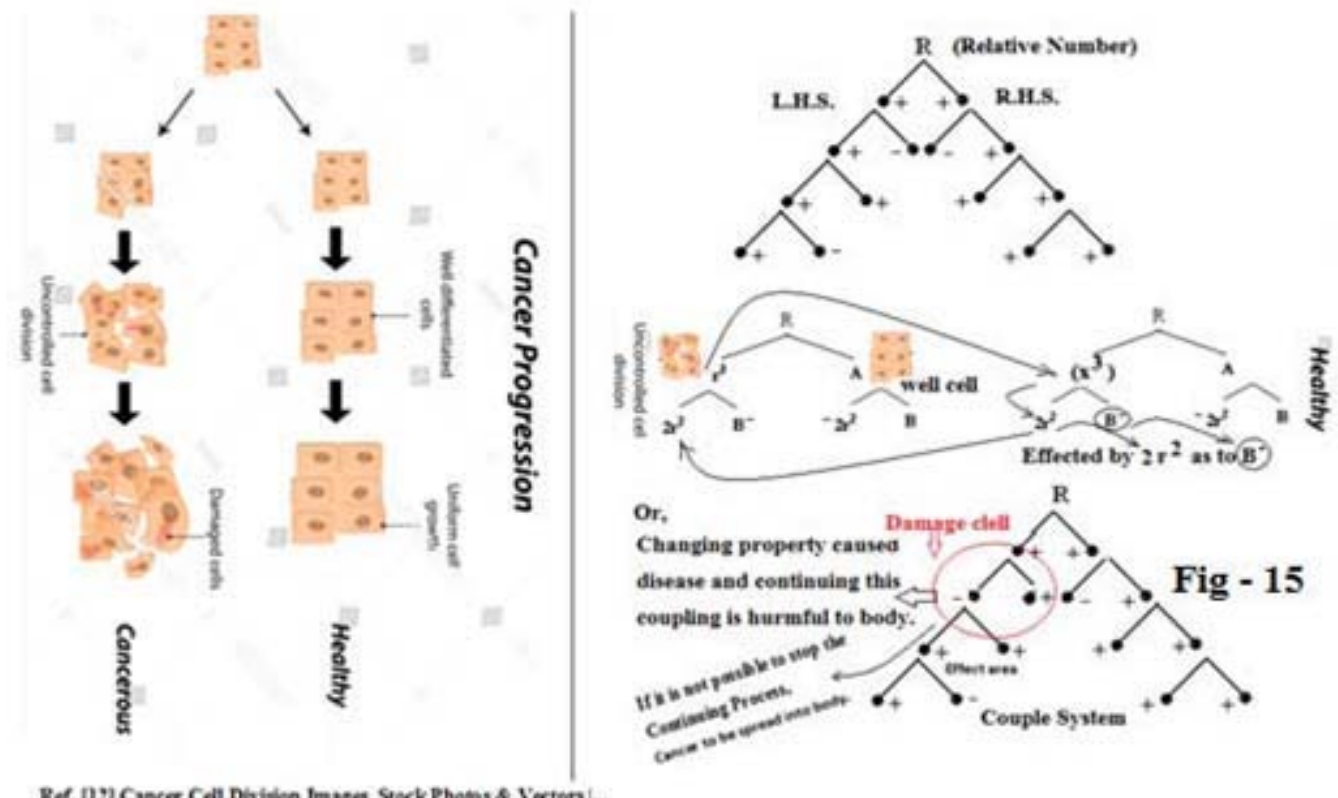

Fig. 15

Fig. 16

The life or decay of corona virus [80]
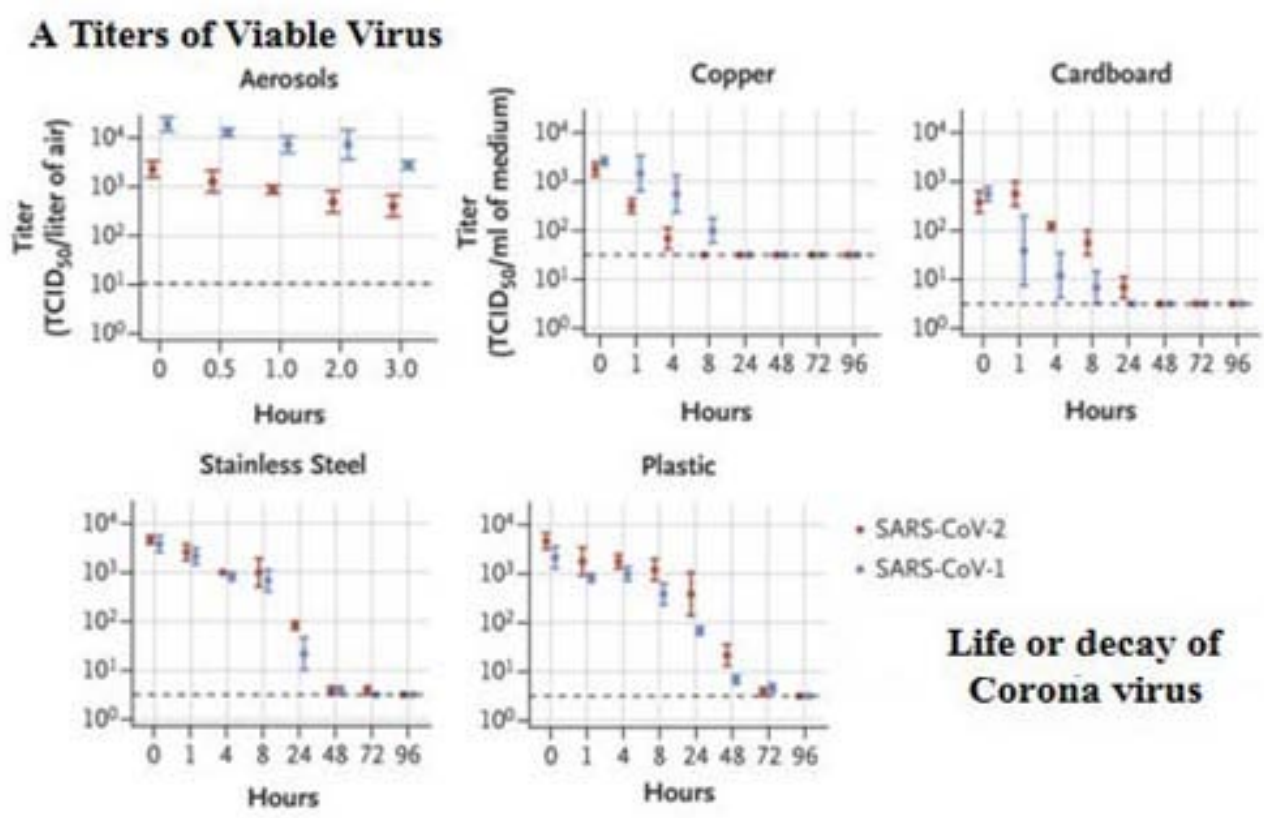

- SARS-COV-2

- SARS-CoV-1

\section{Life or decay of Corona virus}

Fig. 17 
The coupling system of life of corona virus.

We have the equation,

$\mathrm{M}^{0} \times 1 \times 1=1^{0} \times 1 \times 1=1$ number $\left(\mathrm{M}^{0}=1^{0}=1\right.$, when $\left.\mathrm{M}=1\right)$ and 1 number $=1$ hour.

For a titers of viable virus (Aerosols)

1) $\left[\mathrm{M}^{0} \times 1 \times 1\right]=1^{0} \times 1 \times 1=1$ hour.

2) $1 / 2\left[\mathrm{M}^{0} \times 1 \times 1\right]=0.5$ hour.

3) $2\left[\mathrm{M}^{0} \times 1 \times 1\right]=2$ hours.

4) $3\left[\mathrm{M}^{0} \times 1 \times 1\right]=3$ hours

5) $4\left[\mathrm{M}^{0} \times 1 \times 1\right]=4$ hours

For Copper, Cardboard, Stainless steel, Plastic: $\left(M^{0}=10=1\right.$, when $\left.M=1\right)$

a) $2\left[\mathrm{M}^{0} \times 2 \times 1\right]=2[2]=4$ hours on copper.

b) $3\left[\mathrm{M}^{0} \times 2 \times 1\right]=3[2]=6=$ hours on cardboard.

c) $4\left[\mathrm{M}^{0} \times 2 \times 1\right]=4[2]=8=$ hours $6 \times 12=72$ hours on stainless steel and plastic.

d) $5\left[\mathrm{M}^{0} \times 2 \times 1\right]=5[2]=10=$ hours

e) $6\left[\mathrm{M}^{0} \times 2 \times 1\right]=6[2]=12=$ hours, again, $(12 \times 2)=24,(24 \times 2)=48,(48 \times 2)=96$

f) $6\left(6\left[\mathrm{M}^{0} \times 2 \times 1\right]\right)=6(6[2])=72=$ hours. $(72 \times 2)=144$ hours.

Virus spread throughout the word. An example is stated here [81]

\section{Coronavirus 10-day forecast}

\section{As of 22 Mar 10-day forecast Growth rate Curve-flattening index}

\section{Location}

Select Country/Region:

Australia

Raw case numbers:

Total Deaths

$1,549 \quad 7$

Active cases:

Now In 10 days (min-max)

$1,517 \quad 9,831-15,707$

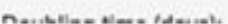

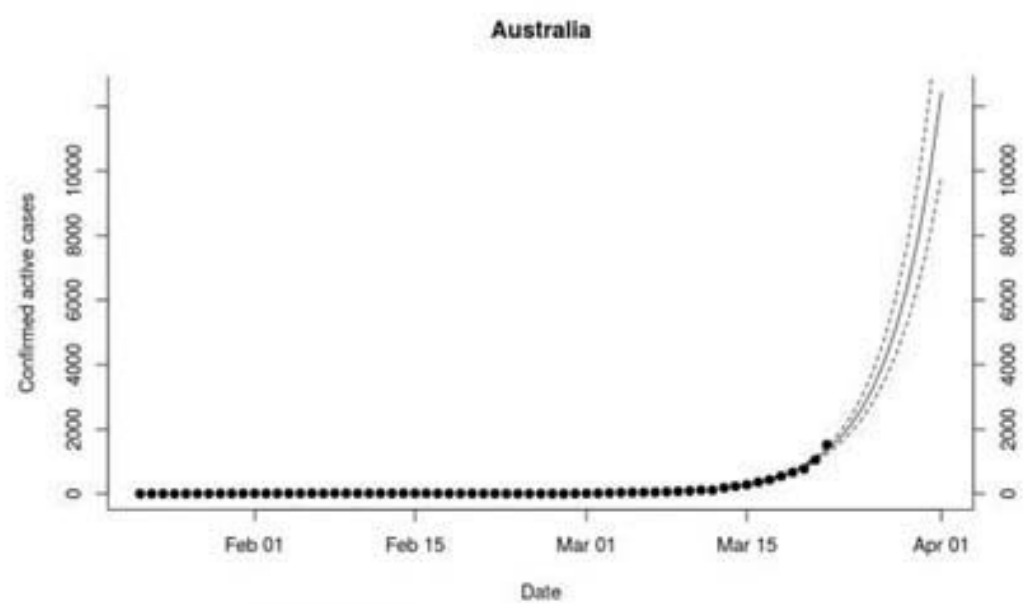

Fig. 18

The app's 10-day forecast for Australia as of 22 March, 2020. Picture: Supplied.

How fast could COVID-19 spread in Australia? And how many people could potentially be infected?

We can't of course know for sure, but we have enough data to make some rough forecasts; and being forewarned is to be forearmed. So we've developed an interactive website that gives a ten-day forecast, by country, on likely numbers of COVID-19 cases. We may compare the above figure of spreading of corona virus in 10 days in Australia with the figure of series of $\mathrm{Pi}[1,2]$ as given here: 




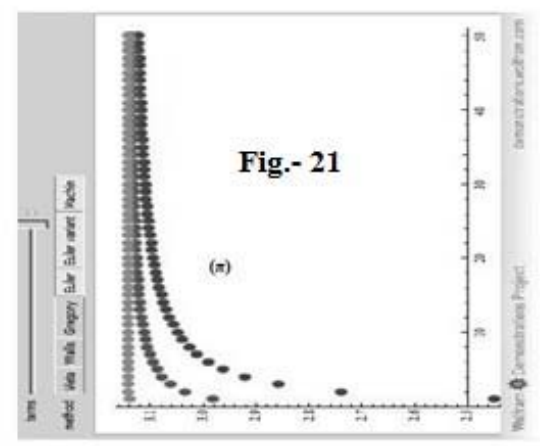

Fig. 21: Reference - Pi Formulas - from Wolfram Math Workd) No: 1437-1445// ISSN.2348.
196x 2015. By Nimalendu Das

From the above comparison of the figures - 19, 20, 21 we may get idea that corona virus spread by obeying the couple system. Corona virus behave like host cells and 'spike' protein. Its hand is unstable. Due to this reason cell attacks body seriously. It is possible to destroy a corona virus cells by destroying the couple protein. All cells are interlinked to a couple systems. Couple breaks means cell will weak \& cannot mixed with each other, at that time medicine can destroy the virus cells forever. Or we may add another protein cell to corona to change its harmful properties through a coupling process. If it is possible to fit cell by micro-cell-fitting- equipment, then no need medicine. Few medicines has side effect, but to rearranging the cell, body will safe from disease.

\section{Brain AND Other Cells}

Neurons are responsible for the transport and uptake of neurotransmitters - chemicals that relay information between brain cells. Depending on its location, a neuron can perform the job of a sensory neuron, a motor neuron, or an interneuron, sending and receiving specific neurotransmitters. In the adult brain, neural circuits are already developed, and neurons must find a way to fit in. As a new neuron settles in, it starts to look like surrounding cells. It develops an axon and dendrites and begins to communicate with its neighbors. The following figure [20] related to the couple system.

\section{a) Death of brain cells}

The lives of some neurons can take abnormal turns. Some diseases of the brain are the result of the unnatural deaths of neurons. Due to Parkinson's disease, Huntington's disease, Alzheimer's disease, Blows to the brain, Spinal cord injury and, other cause cells damaged. When virus attacks or for other causes, cells destroyed. Here we see neuron, oligodendrocyte, astrocyte in the form of a couple systems. This system breaks when the attack by diseased. The reaction of coupling disturbs means cells damaged. We can realize these facts to see the following figure [22].

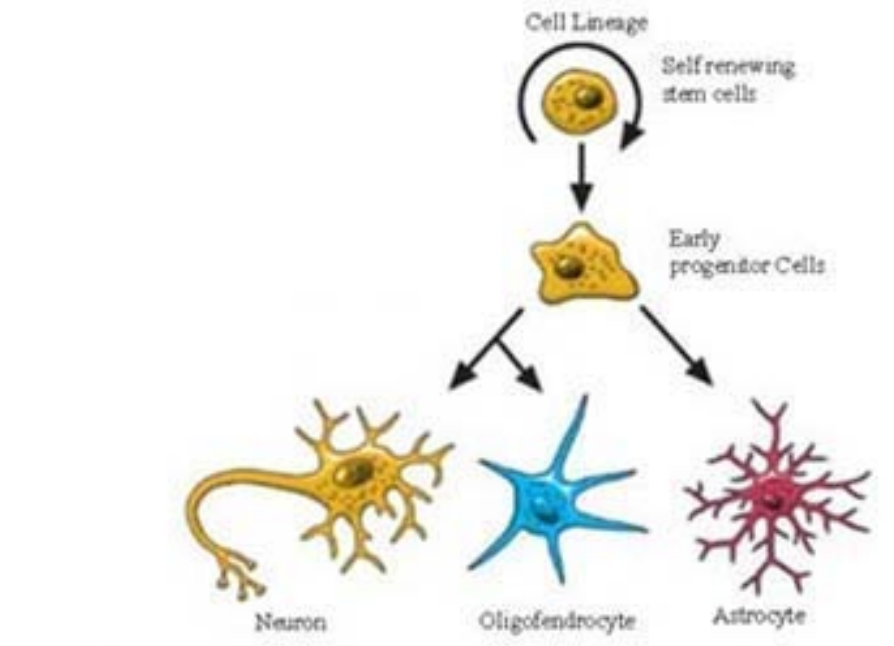

Fig. 22: Stem cells differentiate to produce different types of nerve cells 
b) Death of brain cells

The lives of some neurons can take abnormal turns. Some diseases of the brain are the result of the unnatural deaths of neurons. Due to Parkinson's disease, Huntington's disease, Alzheimer's disease, Blows to the brain, Spinal cord injury and, other cause cells damaged. When virus attacks or for other causes, cells destroyed. Here we see neuron, oligodendrocyte, astrocyte in the form of a couple systems. This system breaks when the attack by diseased. The reaction of coupling disturbs means cells damaged. We can realize these facts to see the following figure [23].
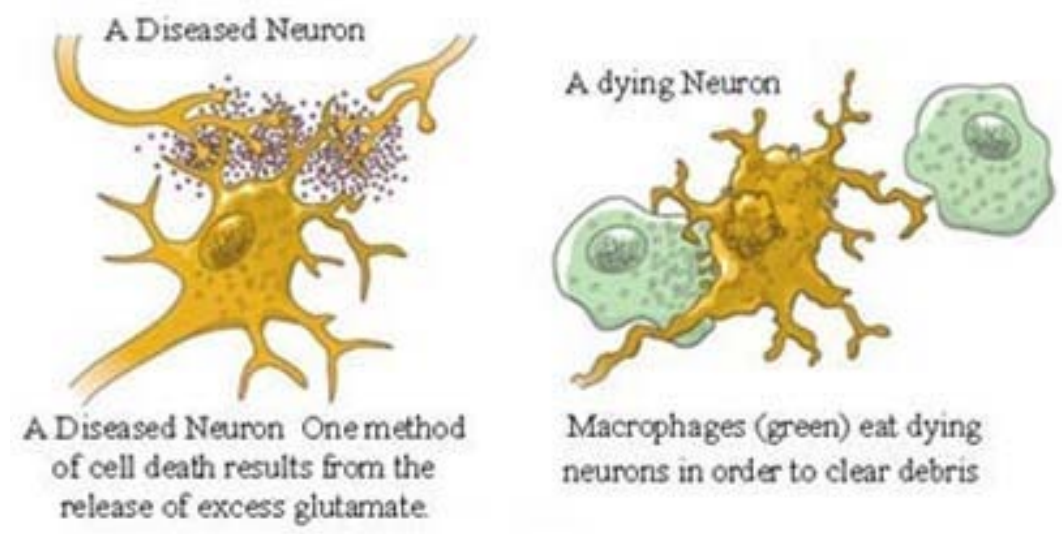

Macrophages (green) eat dying
neurons in onder to clear debris

Fig. 23

So, we need to think in what way a couple to be fit to work cells. The proper medicine has the power to clear diseases and can run a couple in proper ways. We need to know the number of cells worked in a body. It is possible to find many numbers from a couple systems. Therefore, the application of finding of a number of cells is vital one. The following figure of Ependymal cells [14] of the brain functioned as a couple system. If one of the cells breaks to complete its function, then it is to be assumed that memory cells will lose their property. As a result, the number of cells differs from the original format.

So, it needs to function in a body in a properly adding medicine or by sending a messenger to the brain to keep fit. The coupling can multiply by numbers as to produce many cells. Many coupling is possible at a time to yielding a cell's birth also.
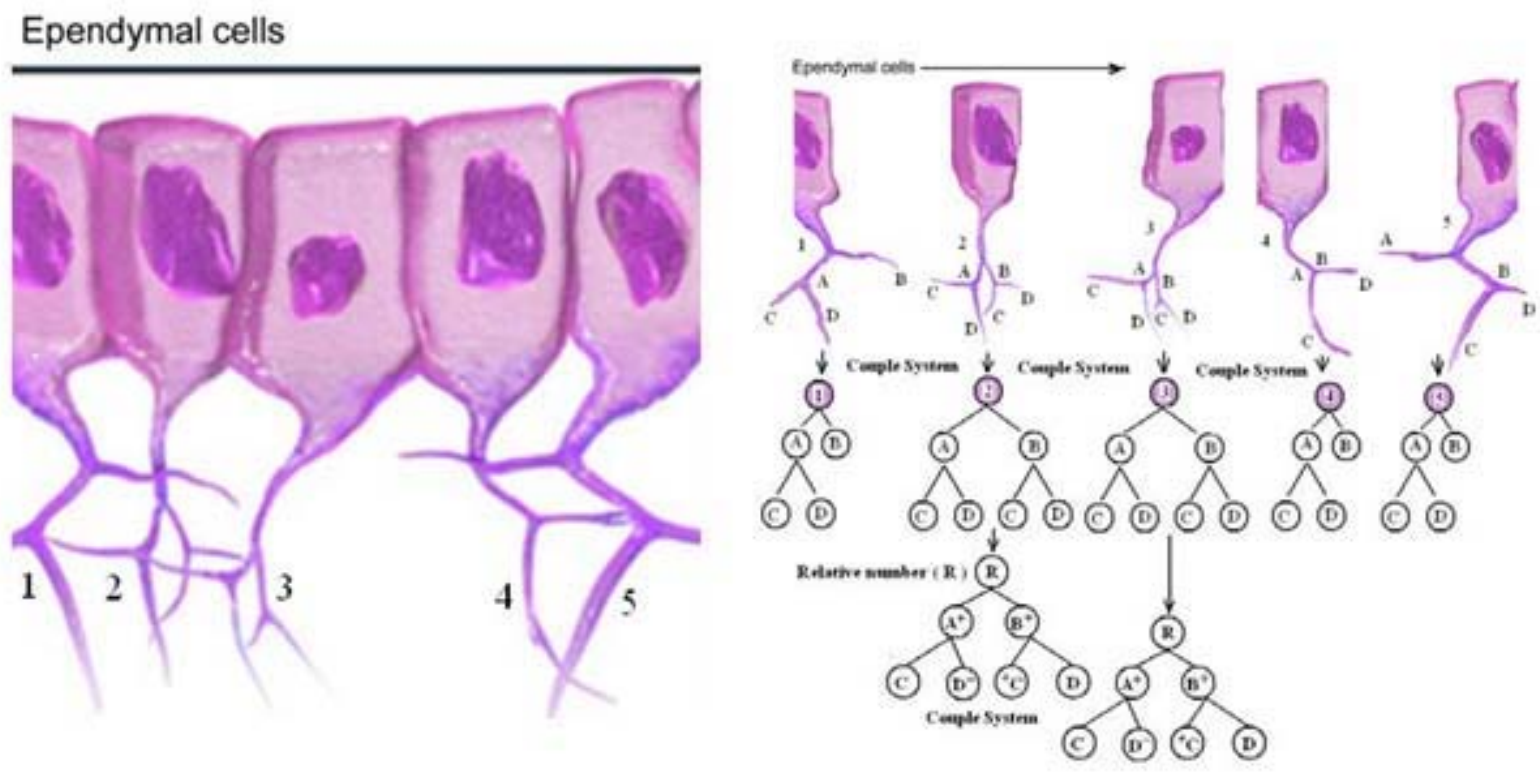

Fig. 24

Functions of Couple System in the Brain Cells, Fig. 24 and 25. 
Another example of the brain cells.

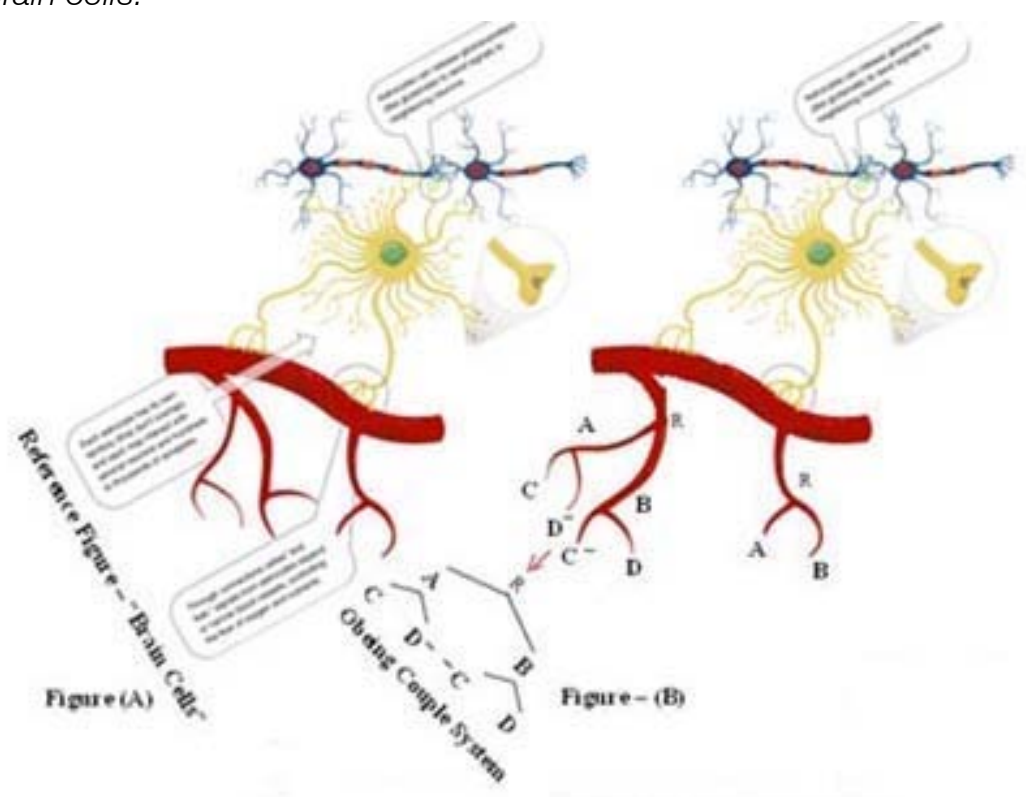

Calculation of the number of cells

$\mathrm{M}^{3} \times 3 \times 2=1^{3} \times 3 \times 2=6000=6 \times 10^{3}=6$ thousand $\times 2=12000$, (11000 Neurons in Pond Snail brain) [9]. Now ratio of $\mathrm{M}^{3} \times 3 \times 2=1^{3} \times 3 \times 2=6000$ number and $\mathrm{M}^{2} \times 2 \times 2=1^{2} \times 2 \times 2=40$ numbers $=6000 / 40=150$. But 6000 / $(3 \times 2)=1000 \& 1000 \times 100=100000$, the number of hairs that someone has on their head can vary by individual. However, the average person has about 100,000 hairs on their head at one time [15]. Again, $150 \times 1000=150000$ number of blonde hair. [15].

$M^{4} \times 3 \times 3=1^{4} \times 3 \times 3=90000=9 \times 10^{4}=0.09$ million $=90$ thousand of red hair [15].

Ratio of $\mathrm{M}^{4} \times 3 \times 3=1^{4} \times 3 \times 3=90000$ and $\mathrm{M}^{3} \times 3 \times 2=1^{3} \times 3 \times 2=6000 \& 90000 / 6000=15$.

$M^{5} \times 4 \times 3=1^{5} \times 4 \times 3=1200000=1.2 \times 10^{6}=1.2$ million. Now, 1.2 million $/ 90000=13.33$.

Application of $1.2 \times 10^{6}$------

Numbers from Couple System

Cells [References]

1) $1.2 \times 10^{6}=1.2$ million A healthy adult male can release between 40 million and 1.2 billion sperm cells in a single ejaculation. [16]

2) $1.2 \times 10^{6}=1.2$ million The number of fibers in human optic nerve $=1,200,000$ [17].

3) $1.2 \times 10^{6} / 3=400000$ The purple structures inside the ovary are immature egg cells, or oocytes. All of the 400,000 egg cells a woman will ever produce are already present in her ovaries when she is born, although the eggs are in an undeveloped form [18] and $400000 / 10=40000$, The human gut alone contains on average: 40,000 bacterial species [25d], $40000 / 2=20000$, According to Asher Mullard, "Between them [the bacteria in our bodies], they harbor millions of genes, compared with the paltry 20,000 estimated in the human genome. [19]

4) 1.2 million / $10=120000$ Number of fibers in cat optic nerve $=119,000[20]$.

5) 1.2 million / $16=75000$ Number of fibers in albino rat optic nerve $=74,800$ [20].

6) $75000 / 10=7500 \quad$ Number of neurons in nucleus of the hypoglossal nerve $7500 /(3 / 2=1.5)=$ $5000 \ldots 4,500-7,500[20]$.

7) $7500 / 2=3750$

8) 1.2 million/100 $=12000$ Number of hair cells in cochlea 12,000 outer hair cells [21]

9) $1200000 /(3 / 2)=800000$ Number of retinal ganglion cells $=800$ thousand to 1 million.

10) $1200000 / \mathrm{V}(3 / 2)=97979.58 \approx 1$ million. Again, $1200000 \times \sqrt{ }(3 / 2)=14.6969 \approx 14.7$ million. There are about 0.7 to 1.5 million retinal ganglion cells in the human retina [22].

11) $800000 / 10=800000$

$800000 / \sqrt{ } 2=565685.42$ Number of neurons in the human LGN 565,835[23]. 
It is not possible to know all cells of all animals in our Earth; these are the examples to support the number yielded from a couple system, and it is related to different cells.

$M^{6} \times 4 \times 4=1^{6} \times 4 \times 4=16000000=1.6 \times 10^{7}=16$ million. Ratio of 16 million $/ 1.2$ million = 13.33:1, for example, Currently the largest artificial neural networks, built on supercomputers, have the size of a frog brain (about 16 million neurons) [20].

$\mathrm{M}^{7} \times 5 \times 4=1^{7} \times 5 \times 4=200000000=2 \times 10^{8}=0.2$ billion $=200$ million $/ 10=20$ million, (Neurons in the brain of rat, 15000000 - 21000000) [24]. Ratio $=200$ million $/ 16$ million $=12.5: 1$

$\mathrm{M}^{8} \times 5 \times 5=1^{8} \times 5 \times 5=25000000000=2.5 \times 10^{9}=2.5$ billion $/ 10=250$ million (Number of fibers in corpus callosum $=250,000,000$ ) [25]. Ratio $=2.5$ billion $/ 0.2$ billion $=12.5: 1$

$\mathrm{M}^{9} \times 6 \times 5=1^{9} \times 6 \times 5=30000000000=3 \times 10^{10}=30$ billion. Ratio $=30$ billion/2.5 billion $=12: 1$.

$\mathrm{M}^{10} \times 6 \times 6=1^{10} \times 6 \times 6=360000000000=36 \times 10^{10}=360$ billion, $1 / 10^{\text {th }}$ of this is number 36 billion. Average number of neocortical glial cells (older adults) $=36$ billion [26].

Ratio $=360$ billion $/ 30$ billion $=12: 1$.

Here we see, when $M^{1} \times 2 \times 1$ then, negative portions is $M^{-1} \times 1 \times 0$, we can arrange this figure as:

Now, $2 / 0=2$

Now, $2 / 0=2$

$\left(M^{1} \times 2 \times 1\right)+\left(M^{-1} \times 1 \times 0\right)=10 \times 2+0=20$

Now, $2 / 0=2$

$\left(M^{1} \times 2 \times 1\right)-\left(M^{-1} \times 1 \times 0\right)=10 \times 2-0=20$

Now, $2 / 0=2$

5) $\quad M^{2} \times 2 \times 2 \times M^{-2} \times 0 \times 0=0$

6) $\left(M^{2} \times 2 \times 2\right) /\left(M^{-2} \times 0 \times 0\right)=100 \times 4 / 0=400$

Now, $4 / 0=4$

7)

$\left(M^{2} \times 2 \times 2\right)+\left(M^{-2} \times 0 \times 0\right)=100 \times 4+0=400$

Now, $4 / 0=4$

Now, $4 / 0=4$

$\left(M^{2} \times 2 \times 2\right)-\left(M^{-2} \times 0 \times 0\right)=100 \times 4-0=400 \times \sqrt{2}=5656.8$, (Neurons in the brain of Jellyfish is 5600) [27]. Again, $400 \times 10=4000$, The ANC is found by multiplying the WBC count by the percent of neutrophils in the blood. For instance, if the WBC count is 8,000 and $50 \%$ of the WBCs are neutrophils, the ANC is $4,000(8,000 \times 0.50=$ 4,000). The most important infection-fighting WBC is the neutrophil (NEW-truh-fil). The number doctors look at is called your absolute neutrophil count (ANC). A healthy person has an ANC between 2,500 and 6,000 [28].

Again, $\left(M^{2} \times 2 \times 2\right)-\left(M^{-2} \times 0 \times 0\right)=100 \times 4-0=400 \times 4=1600$ is for acting as "Within germinal centers, $B$ cells proliferate and mutate the genetic region coding for their surface antibody (also known as immunoglobulin). The process is called somatic hypermutation and is responsible for introducing spontaneous mutations with a frequency of about 1 in every 1600 cell division (a relatively high frequency considering the low mutation frequency of other cells of the body is 1 in $10^{6}$ cell divisions)..." [29].

In this case, for 1600 cell division, when acts with $10^{6}$ cells, then we get $1.6 \times 10^{9}$ cells, and it is equal to $\left(\mathrm{M}^{6} \mathrm{x}\right.$ $4 \times 4)=1.6 \times 10^{6}$, and 1000 times of this value is $=1.6 \times 10^{9}$ or 1.6 billion. Again, $\left(\mathrm{M}^{6} \times 4 \times 4\right)=1.6 \times 10^{6} /(3 / 2)=$ $1.066 \times 10^{6}$ or about 1 million. The total number of Sodium pumps for a small neuron $=1$ million [30]. Again, $\sqrt{ } 1.066 \times 10^{6}$ number $=1032.47$ number and $800 \times \sqrt{ } 1.5=979.79$ number. The scientists estimated that "Researchers have learned a lot about this worm - enough for several Nobel Prizes - and they know that there are exactly 1,031 cells in the adult male and 959 in the adult hermaphrodite (there is no female C. Elegans)" [31].

$$
M^{3} \times 3 \times 2 \times M^{-3} \times 0 \times-1=M^{3} \times M^{-3} \times 3 \times 2 \times 0 \times-1=0
$$

8) $\left(M^{3} \times 3 \times 2\right) /\left(M^{-3} \times 0 \times-1\right)=1000 \times 6 / 0=6000$

9) $\left(M^{3} \times 3 \times 2\right)+\left(M^{-3} \times 0 \times-1\right)=1000 \times 6+0=6000$

10) $\left(M^{3} \times 3 \times 2\right)-\left(M^{-1} \times 0 \times-1\right)=1000 \times 6-0=6000$

11) $\left(M^{4} \times 3 \times 3\right) \times\left(M^{-4} \times-1 \times-1\right)=90000 \times 0.0001=9$, but 90000 The nervous system: more than 90,000 miles of sensations [32] and according to University of Rochester Medical Center (UMRC), these are the normal range of WBCs per microliter of blood (mcL) [33]

\section{Age range $\quad$ WBC count per mcL of blood.}

Newborns $\quad 9000$ to 30000 , let $9000 \times(3 / 2)^{2} \times 3 / 2=3.375=30375 \approx 30000$

Children under 26200 to 17000 , let $9000 / \sqrt{ } 2=6363.9 \approx 6200 \& 9000 \times 2=18000 \approx 17000$

Children over 2 and adults 5000 to 10000 , let $18000 / 4=4500 \approx 5000 \& 9000 \times \sqrt{ } 3 / 2=11022.7 \approx 10000$. Or 9000 is near value of 10000 .

12) $\left(M^{4} \times 3 \times 3\right) /\left(M^{-4} \times-1 \times-1\right)=90000 / 0.0001=9 \times 10^{8}=0.9$ billion $\times 100=90$ billion, application of 90 billion: 
a) $9 \times 10^{8} \times 10=9 \times 10^{9} \times 3=2.7 \times 10^{10}=$ (difference of $5.00 \times 10^{10} \& 3.20 \times 10^{10}$ is $2.7 \times 10^{10}$ cell of mean cell number of Adipocytes and standard deviation of it, An average human adult has 30 billion fat cells with a weight of $30 \mathrm{lbs}$ or $13.5 \mathrm{~kg}[34]$.

b) $9 \times 10^{8} / 6=1.5 \times 10^{8} \approx$ Femoral cartilage cells $\left(1.49 \times 10^{8}\right.$ cells) [35].

c) $9 \times 10^{8} / 7=1.5 \times 10^{8}=1.285 \times 10^{8} \approx 1.23 \times 10^{8}=$ (Humeral head cartilage cells) [35].

d) $9 \times 10^{8} / 11=8.18 \times 10^{7} \approx 8.06 \times 10^{7}=$ (Talus cartilage cells) [35].

e) $4 \times 10^{9}$ cells $/ 2=2 \times 10^{9}=2 \times 10^{9}$ cells (Heart muscle cells) [36].

12) $\left(M^{4} \times 3 \times 3\right)+\left(M^{-4} \times-1 \times-1\right)=90000+0.0001=90000.0001$

13) $\left(M^{4} \times 3 \times 3\right)-\left(M^{-4} \times-1 \times-1\right)=90000-0.0001=89999.9999=90000 \times 10=9$ million,

14) $\left(M^{5} \times 4 \times 3\right) \times\left(M^{-5} \times-1 \times-2\right)=1200000 \times 0.00002=24$

15) $\left(\mathrm{M}^{5} \times 4 \times 3\right) /\left(\mathrm{M}^{-5} \times-1 \times-2\right)=1200000 / 0.00002=6 \times 10^{9}=6$ billion $\times 10=60$ billion $\approx 60.84$ billion glia cells in brain [37].

Discussion: Coefficient of $\mathrm{M}^{5} \& \mathrm{M}^{-5}$ is $(4 \times 3) /(-1 \times-2)=12 / 2=6$, Number of cortical layer $=6$. The percentage of oxygen consumption by white matter $=6$ and by gray matter $=94 \%$ [38].

In general, neuroglial cells are smaller than neurons; there are about 86 billion neurons and 85 billion "nonneuronal" (glial) cells in the human male brain. While that of the cerebellum is only 0.23 (16.04 billion glia; 69.03 billion neurons). The ratio in the cerebral cortex gray matter is 1.48 , and the combined gray and white matter is 3.76. ${ }^{[33]}$ The ratio of the basal ganglia, diencephalon, and brainstem combined is 11.35 [39].

16) We see that, 60 billion $x \sqrt{2}=84.852$ billion $\approx 85$ billion glial cells. Therefore, the equation $\left(M^{5} \times 4 \times 3\right) /\left(M^{-5} \times-1\right.$ $x-2)$ is tallied to glia cells in human brain. Again, in the case of cerebral cortex gray matter is 16.04 billion glia and 69.03 billion neurons. Again, 84.852/3/2) billion $=69.28$ billion $\approx 69.03$ billion neurons. When th is equation takes place in the form of $\left(\mathrm{M}^{5} \times 4 \times 3\right) \times\left(\mathrm{M}^{-5} \times-1 \times-2\right)$, then we get $=1200000 \times 0.00002=24$ number / $(3 / 2)=16$. So, when 69 billion neuron cells will present in brain, then, rest of the glia will 16 billion. Now, 69 billion / 16 billion $=0.23$ (present cerebellum in brain). If glia cell decreased as 16 billion cells $/(3 / 2)$, we get 13.06 billion and then, 13.06 billon $/ 69$ billion $=0.189$ or 0.19 , this factor save from cerebellum attack.

If we arrange, $(4 \times 3) \&(-1 \times-2)$ as $(4+3)=7$ and $1 /(-1 \times-2)=1 / 2=0.5$, now, $7+0.5=7.5 / 2=3.75$ this number brings the ratio of combined gray and white matter in the brain (3.76). Again, $(4-3)=1$ and $1 /(-1 x-2)$ $=1 / 2=0.5$, now, $1+0.5=1.5$ which is almost same value of 1.48 , the ratio of cerebral cortex gray matter. These facts prove that the cells obey the couple system in all respect.

17) $\left(M^{5} \times 4 \times 3\right)+\left(M^{-5} \times-1 \times-2\right)=1200000+0.00002=1200000=1.2$ million $\times 2=2.4$ million. There are about 2.4 million to 3 million ganglion cells in the human visual system.

18) $\left(M^{5} \times 4 \times 3\right)-\left(M^{-5} \times-1 \times-2\right)=1200000-0.00002=1200000=1.2$ million $/(3 / 2)=800000$, (Number of retinal ganglion cells $=800$ thousand to 1 million) [40]

19) $\left(M^{6} \times 4 \times 4\right) \times\left(M^{-6} \times-2 \times-2\right)=16000000 \times 0.000004=64$

20) $\left(M^{6} \times 4 \times 4\right) /\left(M^{-6} \times-2 \times-2\right)=16000000 / 0.000004=400 \times 10^{9}=400$ billion $x \sqrt{2}=565.68$ (In fact, the average male will produce roughly 525 billion sperm cells over a lifetime and shed at least one billion of them per month) [41]. So, 565.68 will be the maximum sperm cells over a life time.

21) $\left(M^{6} \times 4 \times 4\right)+\left(M^{-6} \times-2 \times-2\right)=16000000+0.000004=16000000=16$ million $/ 4=4000000$, (Neurons in the brain of Mouse, 4000000) [9]. But 4000000/40 $=100000$ or $10^{5}$, the average loss of neocortical neurons = 100000 or $10^{5}$ per day [42]. Again, 100000/100 = 1000 and 100000/10 $=10000$ number, number of synapses for a "typical" neuron $=1000$ to 10000 [43].

22) $\left(\mathrm{M}^{6} \times 4 \times 4\right)-\left(\mathrm{M}^{-6} \times-2 \times-2\right)=16000000-0.000004=16000000=16$ million, (Neurons in the brain of Frog, 16000000) [44].

23) $\left(M^{7} \times 5 \times 4\right) \times\left(M^{-7} \times-2 \times-3\right)=200000000 \times 0.0000006=120$

24) $\left(M^{7} \times 5 \times 4\right) /\left(M^{-7} \times-2 \times-3\right)=3.333333333 \times 10^{14}=333 \times 10^{12}=333$ trillion, $3.33 \times 10^{14} / 9=3.737 \times 10^{13}$ or 37.04 trillion, Dr. Bianconi and her colleagues concluded that there were $3.72 \times 10^{13}$ cells in each of us. That is, 37.2 trillion [45].

25) $\left(M^{7} \times 5 \times 4\right)+\left(M^{-7} \times-2 \times-3\right)=200000000+0.0000006=2 \times 10^{8}=200$ million, now $1 / 2$ of this 100 million Number of neuron of Cockroch cells [46]. Again, 100 million $\times 5=500$ million --- An octopus brain is formed by 500 million large neurons (while the human brain is made of roughly 100 billion smaller neurons), but the intelligence of this aquatic creature is comparable with that of the apes. [47].

26) $\left(M^{7} \times 5 \times 4\right)-\left(M^{-7} \times-2 \times-3\right)=200000000-0.0000006=2 \times 10^{8}=200$ million, Brown rat contain 200 million cells [48]. 
On the other hand, we can arrange the series as:

A) $\mathrm{M}^{1} \times 2 \times 1-\mathrm{M}^{0} \times 1 \times 1=20-1=19($ Ratio $=(2 \times 1) /(1 \times 1)=2: 1)$

$M^{2} \times 2 \times 2-M^{1} \times 2 \times 1=400-20=380$, (Neurons in the brain of Roundworm, 302) [49]. Caenorhabditis elegans (roundworm)

(Ratio $=(2 \times 2) /(2 \times 1)=2: 1)$

$M^{3} \times 3 \times 2-M^{2} \times 2 \times 2=6000-400=5600($ Ratio $=(3 \times 2) /(2 \times 2)=3 / 2=1.5: 1)$

B) $M^{4} \times 3 \times 3-M^{3} \times 3 \times 2=90000-6000=84000=8.4 \times 10^{4} \times 3=252000=$ Brain cells of ant is about 250000 [50] $($ Ratio $=(3 \times 3) /(3 \times 2)=3 / 2=1.5: 1)$

$\mathrm{M}^{4} \times 3 \times 3-\mathrm{M}^{3} \times 3 \times 2=90000-6000=84000=8.4 \times 10^{4} \times 3=252000=$ Brain cells of ant is about 250000 [50] (Ratio $=(3 \times 3) /(3 \times 2)=3 / 2=1.5: 1)$

Again, a) $8.4 \times 10^{4} \times 3 / 2=1.26 \times 10^{5}$, (Cell-associated viral loads for sorted memory CD4+ T cells) and it losses day after day from the memory, range from $1 \times 10^{5}$ to $2 \times 10^{5}$ cells) [51]. Therefore, we can increase the memory by adding at least $1.26 \times 10^{5}$ cells to memory through proper medicine. In almost primary stage of couple system this $\mathrm{M}^{4} \times 3 \times 3-\mathrm{M}^{3} \times 3 \times 2$ factors is responsible to loss of memory. b) $8.4 \times 10^{4} \times \sqrt{3} / 2=1.0287 \times 10^{5}$, the average loss of neocortical neurons $=100000$ or $10^{5}$ per day [52]. Both the results are almost same. More investigation is required in this field. $3 / 2$ is the spin of the cells when to be act in time in the reaction.

The decrease in PV-specific CD8 T cells was also even more apparent when the percentage was translated into absolute numbers per spleen, as there was an overall reduction in the size of the spleens of the virus-infected mice at this point (NP38: PV-immune, $5.8 \pm 2.5 \times 10^{5}$; PV + LCMV Armstrong, $2.4 \pm 1.3 \times 10^{5}$; PV + LCMV-clone 13, $1.5 \pm 0.4 \times 10^{5}$ ). We assume that these observed reductions in virus-specific $T$ cells as monitored by intracellular IFN- $\gamma$ production indicate a loss in T cell number instead of just function, because there is a loss in the total number of CD44highCD8+ cells [53].

Now value of

i) For $5.8 \pm 2.5 \times 10^{5}$ cells, $5.8+2.5 \times 10^{5}=8.3 \times 10^{5}$ cells supporting the couple number, $8.4 \times 10^{4} \times 10=8.4 \times 10^{5}$

$5.8-2.5 \times 10^{5}=3.3 \times 10^{5}$ cells supporting the couple number, $8.4 \times 10^{5} / 2 \sqrt{ }(3 / 2)=3.429 \times 10^{5}$

ii) For $2.4 \pm 1.3 \times 10^{5}$ cells, $2.4+1.3 \times 10^{5}=3.7 \times 10^{5}$ cells supporting the couple number, $8.4 \times 10^{4} \times 4=3.36 \times 10^{5}$ $2.4-1.3 \times 10^{5}=1.1 \times 10^{5}$ cells supporting the couple number, $3.36 \times 10^{5} / 3=1.12 \times 10^{5}$

iii) For $1.5 \pm 0.4 \times 10^{5}$ cells,

$1.5+0.4 \times 10^{5}=1.9 \times 10^{5}$ cells supporting the couple number, $8.4 \times 10^{4} \times 2=1.68 \times 10^{5}$

$1.5-0.4 \times 10^{5}=1.1 \times 10^{5}$ cells supporting the couple number, $3.36 \times 10^{5} / 3=1.12 \times 10^{5}$

To calculate these values, we can assume that minimum of $1.26 \times 10^{5}$ cells be active in loss of memory. So, it requires filling the cell in a proper way by adding medicine, which can play in the coupled system to increase memory. 


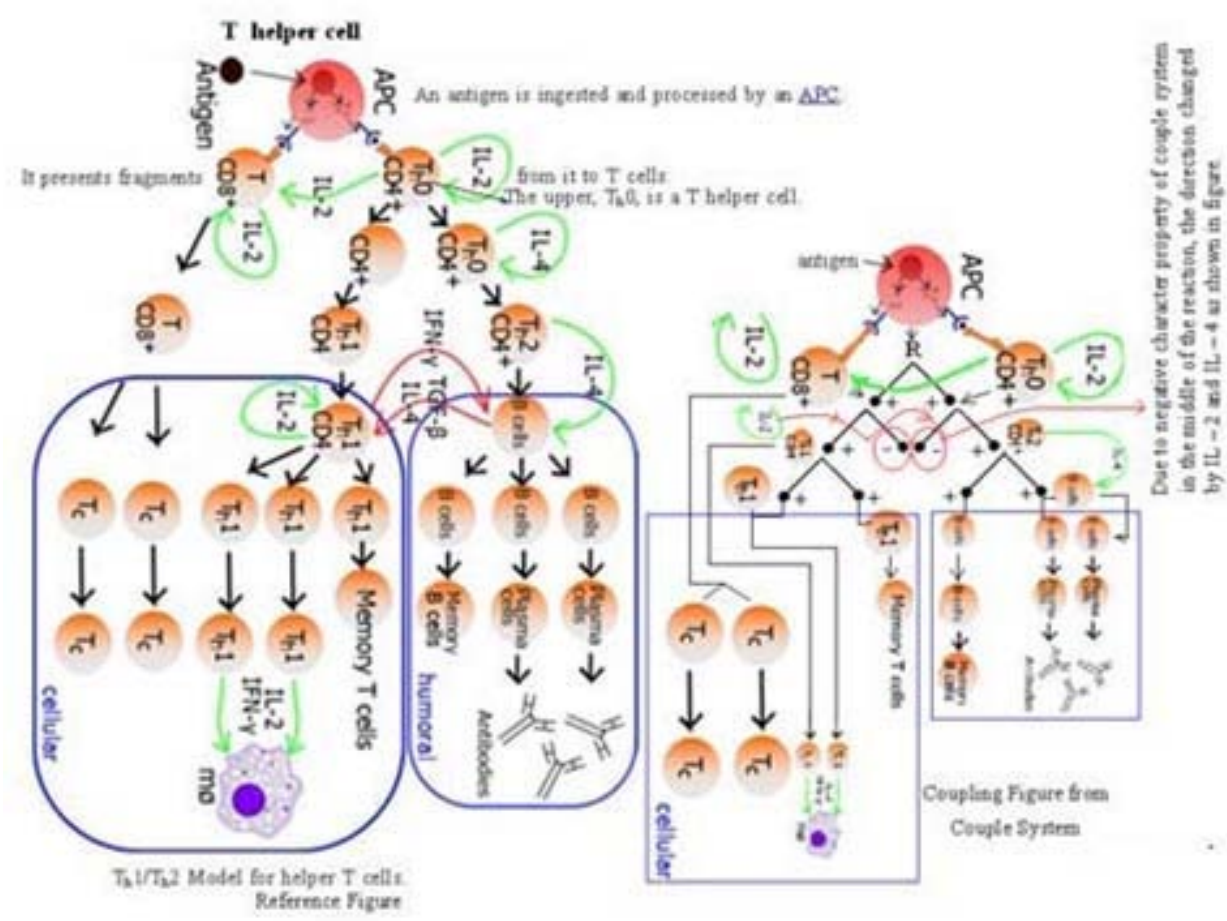

Fig. 26

Cell-associated viral loads for sorted memory CD4+ T cells

C) $\mathrm{M}^{5} \times 4 \times 3-\mathrm{M}^{4} \times 3 \times 3=1200000-90000=1110000=1.1$ million,(Neurons in the brain of Cockroach, 1 million) [54]. (Ratio $=(4 \times 3) /(3 \times 3)=1.3333)$

D) $\mathrm{M}^{6} \times 4 \times 4-\mathrm{M}^{5} \times 4 \times 3=16000000-1200000=14.8 \times 10^{6}=14.8$ million (Ratio $\left.=(4 \times 4) / 4 \times 3\right)=1.7777$. but 14.8 $\times 10^{6} / \sqrt{ }(3 / 2)=12.084 \times 10^{6}$. We see that $1 / 2$ of 12 million or 6 million cone cells and 10 times of 12 million or 120 million rod cells are in human retina [55]. $\quad \mathrm{M}^{7} \times 5 \times 4-\mathrm{M}^{6} \times 4 \times 4=200000000-16000000=1.84 \times 10^{8}=184$ million $\times \sqrt{ } 2=260.2$ million, (Neurons in the brain of Common treeshrew is $261 \times 10^{6}$ cells [56].

E) $M^{8} \times 5 \times 5-M^{7} \times 5 \times 4=2500000000-200000000=2.3 \times 10^{9}=2.3$ billion $\times 10=23$ billion and 23 billion $/ \sqrt{ }(3 / 2)=18.7794$ billion $\approx 19$ billion. [57]. The average number of neocortical neurons was 19 billion in female brains and 23 billion in male brains. in terms of cells for male brain, 23 billion/2 $=11.5$ billion, African Elephant, 11000000000 [58]. $($ Ratio $=(5 \times 5) /(5 \times 4)=1.25$

F) $M^{9} \times 6 \times 5-M^{9} \times 5 \times 5=30000000000-2500000000=27.5 \times 10^{9}=27.5$ billion. $($ Ratio $=(6 \times 5) /(5 \times 5)=1.2$. now $27.5 \times 109 / \sqrt{ }(3 / 2)=22.45 \times 109$ cells in human body. "The average number of neocortical neurons was 19 billion in female brains and 23 billion in male brains."[59]

G) $M^{10} \times 6 \times 6-M^{10} \times 6 \times 5=360000000000-30000000000=330 \times 10^{9}=330$ billion $/ \sqrt{3} / 2=269.44$ billion, (Neurons in the brain of Elephant is 267 billion) [60]. (Ratio $=(6 \times 6) /(6 \times 5)=1.2$

H) $\mathrm{M}^{11} \times 7 \times 6-\mathrm{M}^{11} \times 6 \times 6=4200000000000-360000000000=3840 \times 10^{9}=3840$ billion

Couple shifting type formation: (Ratio $=(7 \times 6) /(6 \times 6)=1.166$

a) $\mathrm{M}^{2} \times 2 \times 2-\mathrm{M}^{0} \times 1 \times 1=400-1=399$

b) $\mathrm{M}^{3} \times 3 \times 2-\mathrm{M}^{1} \times 2 \times 1=6000-20=5980$

c) $M^{4} \times 3 \times 3-M^{2} \times 2 \times 2=90000-400=89600$

d) $\mathrm{M}^{5} \times 4 \times 3-\mathrm{M}^{3} \times 3 \times 2=1200000-6000=1194000=1.194$ million

e) $\mathrm{M}^{6} \times 4 \times 4-\mathrm{M}^{4} \times 3 \times 3=16000000-90000=15910000=15.91$ million

f) $M^{7} \times 5 \times 4-M^{5} \times 4 \times 3=200000000-1200000=198800000=198.8$ million $\times 2=3.976 \times 10^{8}$, (Neuron of Octopus - 300,000,000/500,000,000) [61].

$M^{8} \times 5 \times 5-M^{6} \times 4 \times 4=2500000000-16000000=2484000000=2.484$ billion $\times 4=9.9 \times 109 \approx 10$ billion, Neuron of False killer whale, 10500000000 and 2.484 billion $\times 2=4.968$ billion, Neuron cells of Greater Kudu [62].

$\mathrm{M}^{8} \times 5 \times 5-\mathrm{M}^{6} \times 4 \times 4=2500000000-16000000=2484000000=2.484$ billion. Now,

2.484 billion $\times 3=7.452$ billion and 2.484 billion $\times 4 / \sqrt{ } 1.5=8.1127$ billion

It was estimated that long-finned pilot whales have an average of $2.3 \times 10^{9}$ neurons and $8.3 \times 10^{9} \mathrm{glial}$ cells in the auditory cortex, and $2.3 \times 10^{9}$ neurons and $7.6 \times 10^{9}$ glial cells in the visual cortex. [63]. 
g) $M^{9} \times 6 \times 5-M^{7} \times 5 \times 4=30000000000-200000000=29.8$ billion $\times \sqrt{ } 1.5=36.13$ billion, Neurons of Long-finned pilot whale, 37200000000 [64].

h) $\mathrm{M}^{10} \times 6 \times 6-\mathrm{M}^{8} \times 5 \times 5=360000000000-2500000000=357.5$ billion. Here we see that 40 times of $2.5 \times 10^{9}$ is $10^{11}$ or 100 billion, average number of neurons in the brain is 100 billion [65].

i) $\mathrm{M}^{11} \times 7 \times 6-\mathrm{M}^{9} \times 6 \times 5=4200000000000-30000000000=4.17 \times 10^{12}=4170$ billion

$\mathrm{M}^{12} \times 7 \times 7-\mathrm{M}^{10} \times 6 \times 6=49000000000000-360000000000=4.864 \times 10^{13}=48.64$ trillion, 48.64 trillion $\times 2=97.28$ trillion $\approx$ about 100 trillion atom $\approx$ cells for human body [66] (Another way of looking at it is that this is $100,000,000,000,000$ or 100 trillion atoms. Interestingly, the number of cells in the human body is estimated to be about the same as the number of atoms in a human cell). We can determine more accurate value as $49 \times 10^{12} \times 2=$ 98 trillion $\approx 100$ trillion.

48.64 trillion $\mathcal{N}(3 / 2)=39.7144$ trillion \& $48.64 / \sqrt{ } 2$ trillion $=34.3496$ trillion, now, average is $(39.7144+34.3496)$ trillion $/ 2=37.032$ trillion or $3.7032 \times 10^{13}$ that we can consider as cell in human body. [As per reference, probably the best we have, falls closer to the low end: Dr. Bianconi and her colleagues concluded that there were $3.72 \times 10^{13}$ cells in each of us. That is, 37.2 trillion [67].

Odd - odd function:

$\mathrm{M}^{11} \times 7 \times 6-\mathrm{M}^{9} \times 6 \times 5=4,2 \times 10^{12}-3 \times 10^{10}=4.17 \times 10^{12}$ \& ratio $=(7 \times 6) /(6 \times 5)=1.4$

Even - even function:

$\mathrm{M}^{12} \times 7 \times 7-\mathrm{M}^{10} \times 6 \times 6=4.9 \times 10^{13}-3.6 \times 10^{11}=4.864 \times 10^{13} \&$ ratio $=(7 \times 7) /(6 \times 6)=1.36$

Even - odd function:

$\mathrm{M}^{12} \times 7 \times 7-\mathrm{M}^{11} \times 7 \times 6=4.9 \times 10^{13}-4.2 \times 10^{12}=4.48 \times 10^{13} \&$ ratio $=(7 \times 7) /(7 \times 6)=1.166$

Now, $\sqrt{ } 4.48 \times 10^{13}=6693280$ and $6693280 \times(3 / 2)=10.04 \times 10^{6}$ this value is equivalent to animal adult zebrafish $\approx$ 10000000 neuron in the brain. [68]

Odd - odd function:

$M^{13} \times 8 \times 7-M^{11} \times 7 \times 6=5.6 \times 10^{14}-4.2 \times 10^{12}=5.558 \times 10^{14}$ \& ratio $=(8 \times 7) /(7 \times 6)=1.33$

Now, $\sqrt{5} .558 \times 10^{14}=23575410.9$, this value is equivalent to 23000000 of Mechow's mole rat or 24000000 cells of Hedgehog [69]

Even - odd function:

$\mathrm{M}^{14} \times 8 \times 8-\mathrm{M}^{13} \times 8 \times 7=6.4 \times 10^{15}-5.6 \times 10^{14}=5.84 \times 10^{15}$ \& ratio $=(8 \times 8) /(8 \times 7)=1.14$

Now, $\sqrt{ } 5.84 \times 10^{15}=76419892$, this value equivalent to 762570000 cells of Gearter kudu [70].

Odd - odd function:

$\mathrm{M}^{15} \times 9 \times 8-\mathrm{M}^{13} \times 8 \times 7=7.2 \times 10^{16}-\mathrm{M}^{13} \times 8 \times 7=7.144 \times 10^{16} \&$ ratio $=(9 \times 8) /(8 \times 7)=1.28$

Now, $\sqrt{ } 7.144 \times 10^{16}=267282622$ this value equivalent to 258000000 cells of Cockatiel [71].

For higher derivatives do not apply to living bodies, cells probably will not be permitted to build their bodies. The individual body has its limited power to form cells. Again, from g): $M^{9} \times 6 \times 5-M^{7} \times 5 \times 4=30000000000-$ $200000000=29.8$ billion 30 billion $\times \sqrt{ } 1.5=36.74$ billion, Neurons of Long-finned pilot whale, 37200000000 . Again, 30 billion $\times 3=90$ billion, Number of neurons in the Human Nervous System $-\sim 90$ billion Number of glial cells [72].

For a long time, scientific estimates of the number of cells in the human body ranged between $10^{12}$ and $10^{16}[73]$

$M^{16} \times 10 \times 10-M^{15} \times 9 \times 8=10^{18}-7.2 \times 10^{16}=9.28 \times 10^{17}$, but $9.28 \times 10^{17} / \sqrt{ }(3 / 2)=7.577 \times 10^{17}$ it is 75.77 times larger value than $10^{16}$. Maximum limitation of cell number. 
How couple equation acts on the body, few examples are there: [74]

\begin{tabular}{|c|c|c|c|}
\hline Name & $\begin{array}{l}\text { Neurons in the } \\
\text { brain/whole } \\
\text { nervous system }\end{array}$ & Synapses & Details \\
\hline Sponge & 0 & $\begin{array}{l}M^{[2+2(N-2)]} \cdot N r .(N-2) r \rightarrow M^{0} .0 \times r .(0- \\
2) r=0, \text { when } N=0\end{array}$ & \\
\hline Trichoplax & 0 & $\begin{array}{l}M^{[2+2(N-2)]} \cdot N r .(N-2) r \rightarrow M^{0} .0 \times r .(0- \\
2) r=0, \text { when } N=0\end{array}$ & $\begin{array}{l}\text { Despite no nerve } \\
\text { system, it exhibite } \\
\text { a coordinated } \\
\text { feeding and } \\
\text { behaviors.[4] }\end{array}$ \\
\hline Asplanchna brightwellii (rotifer) & about 200 & $\begin{array}{l}M^{[2+2(N-2)]} \cdot N r . N r \rightarrow M^{2} .2 r \cdot 2 r \text {, when, } N= \\
\text { 2. } N>1 \text {, if, } M=r=1, M 2.2 r \cdot 2 r=400 \text { \& } \\
400 / 2=200\end{array}$ & Brain only \\
\hline$\frac{\text { Ciona intestinalis larva (sea }}{\text { squirt) }}$ & 231 & $\begin{array}{l}M^{[2+2(N-2)]} \cdot N r . N r \rightarrow M^{4} \cdot 3 r .3 r \text {, when, } N= \\
\text { 3. If } M=r=1 \text {, then, } M^{4} \cdot 3 r \cdot 3 r=9000 \text { near } \\
\text { value of } 8617 \text {. }\end{array}$ & \\
\hline $\begin{array}{r}\text { Caenorhabditis } \\
\text { elegans (roundworm) }\end{array}$ & 302 & $\begin{array}{l}M^{[1+2(N-2)]} \cdot N r .(N-1) r \rightarrow M^{3} \cdot 3 r \cdot 2 r \text {, when, } \stackrel{-7.500}{N} \\
=3 \text {, and } M^{[2+2(N-2)]} . N r \cdot N r \rightarrow M^{4} .3 r .3 r \\
\text { when, } N=3 . \text { if } M=r=1 \text {, then average } \\
\text { number }=\left(M^{3} .3 r .2 r+M^{4} .3 r .3 r\right) / 2=(6000 \\
+9000) / 2=7500 .\end{array}$ & $\begin{array}{r}\text { is the only } \\
\text { organism to have } \\
\text { its } \\
\text { whole connectom } \\
\text { e (neuronal "wiring } \\
\text { diagram") } \\
\text { completed.[9][10] } \\
{[11]}\end{array}$ \\
\hline Jellyfish & 5,600 & $\begin{array}{l}\left(M^{2} \times 2 \times 2\right)-\left(M^{-2} \times 0 \times 0\right)=100 \times 4-0= \\
400 \times \sqrt{ } 2=5656.8\end{array}$ & $\begin{array}{c}\text { Hydra vulgaris (H. } \\
\text { attenuate) }\end{array}$ \\
\hline Megaphragma mymaripenne & 7,400 & $\begin{array}{l}M^{4} .3 r .3 r=9000 N 1.5=7348.5 \approx 7350 \\
\text { Whern } M=r=1\end{array}$ & \\
\hline Box jellyfish & $8,700-17,500$ & $\begin{array}{l}M^{4} \cdot 3 r \cdot 3 r=9000 \text { and } \\
2\left(M^{4} \cdot 3 r \cdot 3 r\right)=18000 \\
\approx 17,500 .\end{array}$ & $\begin{array}{l}\text { adult Tripedalia } \\
\text { cystophora ( } 8 \mathrm{~mm} \\
\text { diameter) - does } \\
\text { not include } 1000 \\
\text { neurons in each } \\
\text { of the } \\
\text { four rhopalia }\end{array}$ \\
\hline Medicinal leech & 10,000 & $\begin{array}{l}M^{[1+2(N-2)]} \cdot N r .(N-1) r \rightarrow M^{3} .3 r .2 r \text {, when, } \\
N=3 \text {.if } M=r=1 \text {, then } M^{3} .3 r .2 r=6000 \\
\text { but coefficient of } M^{3} \text { is } 3 r .2 r . \text { If } M^{3} .3 r .2 r / 3 r .2 r \\
=1000\end{array}$ & \\
\hline
\end{tabular}




\begin{tabular}{|c|c|c|c|}
\hline Name & $\begin{array}{l}\text { Neurons in the } \\
\text { brain/whole } \\
\text { nervous system }\end{array}$ & Synapses & Details \\
\hline Pond snail & 11,000 & $\begin{array}{l}M^{3} \times 3 \times 2=13 \times 3 \times 2=6000=6 \times 10^{3}= \\
6000 \times 2=12000 \approx 11000\end{array}$ & \\
\hline \multirow[t]{2}{*}{ Sea slug } & 18,000 & $M^{4} .3 r \cdot 3 r=90000$ and & \\
\hline & & $2 x\left(M^{4} \cdot 3 r \cdot 3 r\right)=18000$ & \\
\hline Amphioxus & 20,000 & $\begin{array}{l}M^{[1+2(N-2)]} \cdot N r .(N-1) r \rightarrow M^{3} \cdot 3 r \cdot 2 r \text {, when, } \\
N=3 \text {,if } M=r=1 \text {, then } M^{3} \cdot 3 r \cdot 2 r=6000 \\
\text { but coefficient of } M^{3} \text { is } 3 r .2 r . \text { If } M^{3} \cdot 3 r .2 r / 3 r .2 r \\
=1000 \text {. If we multiplv } 1000 \times 20=20000 \text {. }\end{array}$ & $\begin{array}{l}\text { central nervous } \\
\text { system only }\end{array}$ \\
\hline Larval zebrafish & 100,000 & $\begin{array}{l}M^{[1+2(N-2)]} \cdot N r .(N-1) r \rightarrow M^{3} .3 r .2 r \text {, when, } \\
N=3 \text { if } M=r=1 \text {, then } M^{3} \cdot 3 r .2 r=6000 \\
\text { but coefficient of } M^{3} \text { is } 3 r .2 r . \text { If } M^{3} .3 r .2 r / 3 r .2 r \\
=1000 \text {. If we multiplv } 1000 \times 100=100000\end{array}$ & \\
\hline Lobster & 100,000 & $\begin{array}{l}M^{[1+2(N-2)]} \cdot N r .(N-1) r \rightarrow M^{3} .3 r .2 r \text {, when, } \\
N=3 \text {.if } M=r=1 \text {, then } M^{3} \cdot 3 r .2 r=6000 \\
\text { but coefficient of } M^{3} \text { is } 3 r .2 r . \text { If } M^{3} .3 r .2 r / 3 r .2 r \\
=1000 \text {. If we multiply } 1000 \times 100=100000\end{array}$ & \\
\hline Fruit fly & 250,000 & $\begin{array}{lr}M^{4} \times 3 \times 3-M^{3} \times 3 \times 2=90000-6000= & <10,000,000 \\
84000=8.4 \times 10^{4} \times 3=252000 \approx 250,000\end{array}$ & $\begin{array}{l}\text { In } 2020 \text { a } \\
\text { research group } \\
\text { announced the } \\
\text { most } \\
\text { sophisticated } \\
\text { connectome [23] }\end{array}$ \\
\hline Ant & 250,000 & $\begin{array}{l}M^{4} \times 3 \times 3-M^{3} \times 3 \times 2=90000-6000= \\
84000=8.4 \times 10^{4} \times 3=252000 \approx 250,000\end{array}$ & Varies per species \\
\hline Honey bee & 960,000 & 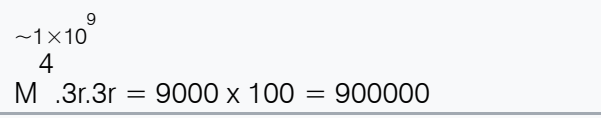 & \\
\hline Cockroach & $1,000,000$ & $\begin{array}{l}M^{[1+2(N-2)]} \cdot N r .(N-1) r \rightarrow M^{3} \cdot 3 r .2 r \text {, when, } \\
N=3 \text {,if } M=r=1 \text {, then } M^{3} \cdot 3 r .2 r=6000 \\
\text { but coefficient of } M^{3} \text { is 3r.2r. If } M^{3} \cdot 3 r \cdot 2 r / 3 r .2 r \\
=1000 \text {. If we multiply } 1000 \times 1000= \\
1000000\end{array}$ & \\
\hline Guppy & $4,300,000$ & $\left(M^{5} \times 4 \times 3=1^{5} \times 4 \times 3\right) \times 4==4800000$ & \\
\hline Adult zebrafish & $\sim 10,000,000$ & {$\left[\left(M^{5} \times 4 \times 3=1^{5} \times 4 \times 3\right) /(4 \times 3)\right] \times 10=$} & $\begin{array}{l}\text { cells } \\
\text { (neurons + other) }\end{array}$ \\
\hline
\end{tabular}




\begin{tabular}{|c|c|c|c|}
\hline Name & $\begin{array}{l}\text { Neurons in the } \\
\text { brain/whole } \\
\text { nervous system }\end{array}$ & Synapses & Details \\
\hline & & 1000000 & \\
\hline Frog & $16,000,000$ & $M^{6} \times 4 \times 4=1^{6} \times 4 \times 4=16000000$ & \\
\hline Naked mole-rat & $26,880,000$ & $\begin{array}{l}\left.{ }^{6}\left(M^{6} \times 4 \times 4=1^{6} \times 4 \times 4\right)\right] \times 2=32000000 \\
/ \sqrt{ } 1.5=26127890.59\end{array}$ & \\
\hline Smoky shrew & $36,000,000$ & $\begin{array}{l}\Gamma^{4} \times 3 \times 31 \times 4=\left\lceil 1^{4} \times 3 \times 3\right\rceil \times 4=\lceil 90000\rceil \times \\
4=360000 \text { and }\lceil 360000\rceil \times 100=36000000\end{array}$ & \\
\hline Short-tailed shrew & $52,000,000$ & $\begin{array}{l}\left.\left.{ }^{6}{ }^{6} \times 4 \times 4=1^{6} \times 4 \times 4\right)\right] \times 4=64000000 \\
/ \sqrt{ } 1.5=52.2255781 .18\end{array}$ & \\
\hline Hottentot golden mole & $65,000,000$ & $\left\lceil\left(M^{6} \times 4 \times 4=1^{6} \times 4 \times 4\right)\right\rceil \times 4=64000000$ & \\
\hline House mouse & $71,000,000$ & $\begin{array}{l}\left.\left.{ }^{6} \times 4 \times 4=1^{6} \times 4 \times 4\right)\right\rceil \times 4=[64000000 \times \\
\sqrt{ } \times 1 \times 10^{12} \\
\sqrt{ } 1.2+64000000 \times \sqrt{ } 1.3] / 2=71539857.28\end{array}$ & \\
\hline Nile crocodile & $80,500,000$ & 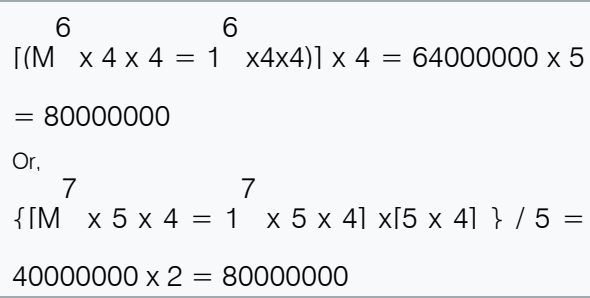 & \\
\hline Golden hamster & $90,000,000$ & $M^{4} .3 r .3 r=9000 \times 10000=90000000$ & \\
\hline Ansell's mole-rat & $103,000,000$ & & \\
\hline Mashona mole-rat & $113,000,000$ & $\begin{array}{l}\left.M^{6} \times 4 \times 4=1^{6} \times 4 \times 4\right) 1 \times 10=160000000 \\
/ \sqrt{ } 2=113137085\end{array}$ & \\
\hline$\underline{\text { Hairy-tailed mole }}$ & $124,000,000$ & $\begin{array}{l}M^{7} \times 5 \times 4-M^{5} \times 4 \times 3=200000000- \\
1200000=198800000 \\
=198.8 \text { million }=\end{array}$ & \\
\hline
\end{tabular}




\begin{tabular}{|c|c|c|c|}
\hline Name & $\begin{array}{l}\text { Neurons in the } \\
\text { brain/whole } \\
\text { nervous system }\end{array}$ & Synapses & Details \\
\hline & & $\begin{array}{l}0.1988 \times 10^{9} / 16=12425000 \times 10= \\
124250000\end{array}$ & \\
\hline Eastern rock elephant shrew & $129,000,000$ & $\begin{array}{l}100 \times\left(M^{6} \times 4 \times 4\right)=1.6 \times 10^{6} / V(3 / 2)=1.306 \\
8{ }^{8} \approx 129.000 .000\end{array}$ & \\
\hline$\underline{\text { Star-nosed mole }}$ & $131,000,000$ & $\begin{array}{l}M^{7} \times 5 \times 4-M^{5} \times 4 \times 3=200000000- \\
1200000=198800000=198.8 \text { million }= \\
0.1988 \times 10^{9} / 1.5=132533333\end{array}$ & \\
\hline Zebra finch & $131,000,000$ & Do & Brain only \\
\hline Silvery mole-rat & $148,000,000$ & $\begin{array}{l}\left.{ }^{6}\left(M^{6} \times 4 \times 4=1^{6} \times 4 \times 4\right)\right] \times 10=1600000000 \times \\
3=148000000\end{array}$ & \\
\hline Four-toed elephant shrew & $157,000,000$ & $\begin{array}{l}\left.{ }^{6}\left(M^{6} \times 4 \times 4=1^{6} \times 4 \times 4\right)\right] \times 10=160000000 \times \\
3=148000000 \times \sqrt{ } 1.1=155223709\end{array}$ & \\
\hline Eurasian blackcap & $157,000,000$ & Do & \\
\hline Goldcrest & $164,000,000$ & $\begin{array}{l}\left.{ }^{6}\left(M^{6} \times 4 \times 4=1^{6} \times 4 \times 4\right)\right] \times 10=160000000 \times \\
3=148000000 \times 1.1=162800000\end{array}$ & \\
\hline
\end{tabular}

\section{iII. Regarding Brain Cells}

Herculano-Houzel and her colleagues used this technique to analyze the brains of four deceased men and published their results in 2009: they consistently found whole human brain glia to neuron ratio of almost 1:1. Specifically, they found that the human brain contains about 170.68 billion cells, 86.1 billion of which are neurons, and 84.6 billion of which are glial cells. Their study also suggests that the ratio of glia to neurons differs dramatically from one general brain region to the next. 60.84 billion cells in the cerebral cortex are glia, while only 16.34 billion cells are neurons, giving this region glia to neuron ratio of about 3.76 to 1 . It's the inverse in the cerebellum, an evolutionarily ancient part of the brain that sits astride the brain stem.

According to Herculano-Houzel's study, the cerebellum contains 69.03 billion neurons and only 16.04 glial cells, which means there are about 4.3 neurons for every glia in this region. [75]. If we apply the relative number of couple system \& classify, we can get different numbers of the brain and shown in Fig 27- Brain here. 


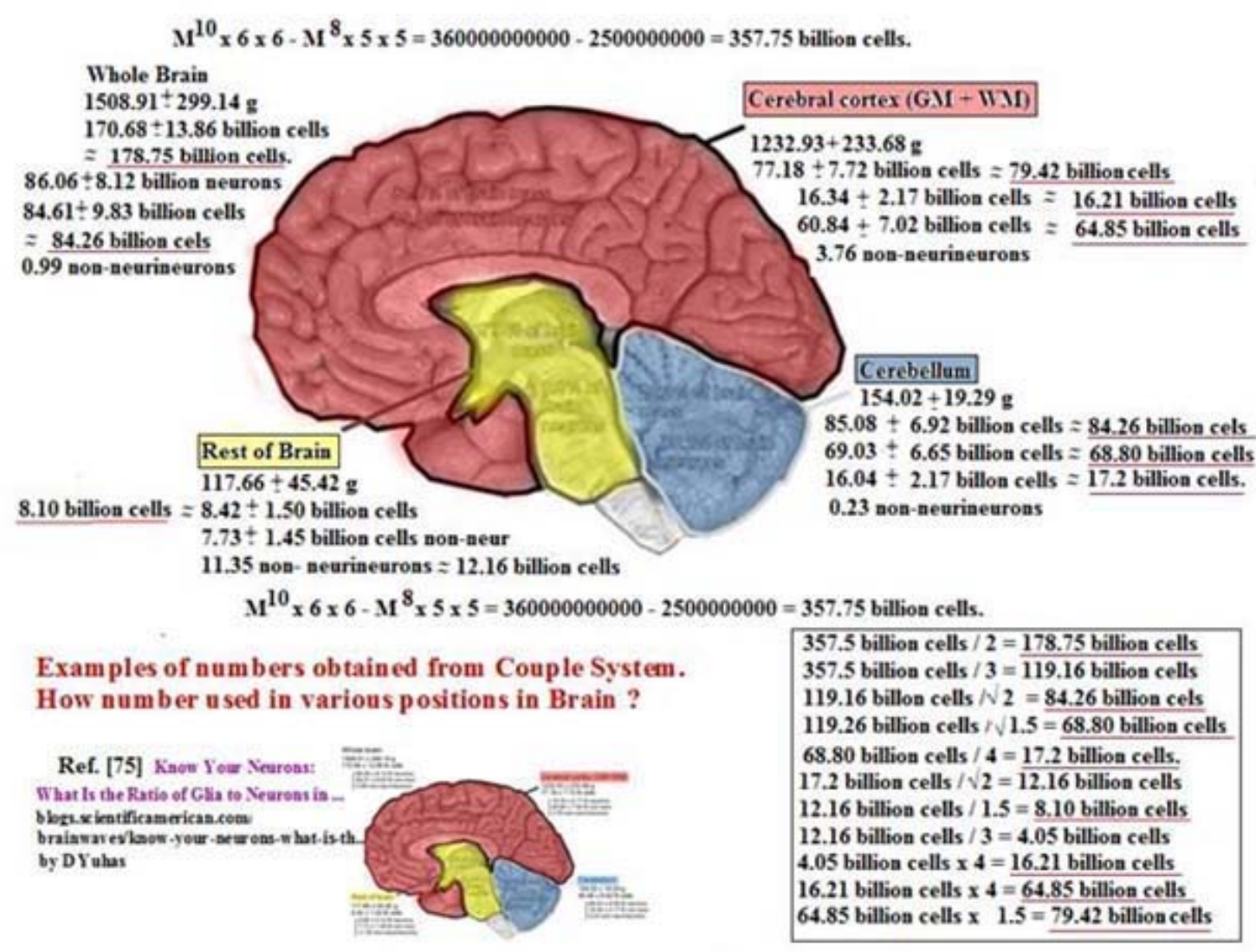

Fig. 27: Coupling mechanism of Brain Cells

Adapted from "Equal Numbers of Neuronal and Nonneuronal Cells Make the Human Brain an Isometrically Scaled-Up Primate Brain"

\section{a) Memory (Mind \& its activity)}

What is gray matter in the brain?

According to reference [76], the grey matter is mainly composed of neuronal cell bodies and unmyelinated axons. Axons are carrying signals between those bodies. The grey matter serves to process information in the brain. Structures within the grey matter process signals generated in the sensory organs or other areas of the grey matter. These signals reach the grey matter through myelinated axons that make up the bulk of the white matter in the cerebrum, cerebellum, and spine. Also found in the grey matter are the glial cells (astroglia and oligodendrocytes) and capillaries. The glial cells transport nutrients and energy to the neurons and may even influence how well the neurons function and communicate.

\section{What is the white matter in the brain?}

White matter, on the other hand, is mainly composed of long-range myelinated axons (that transmit signals to the grey matter) and very few neuronal cell bodies. Myelin forms a protective coating around these axons, insulating them and improving their transmission of neuronal signals. White matter is found buried in the inner layer of the brain's cortex, while the grey matter is mainly located on the surface of the brain. The spinal cord is arranged in the oppositely way, with grey matter found deep inside its core and the insulating white matter wrapped around the outside. Some grey matter is also found deep inside the cerebellum in the basal ganglia, thalamus, and hypothalamus and white matter is also found in the optic nerves and the brainstem. How Gray and White Matter functioned through a couple system, that is given here. Glia and neuron cells are present in the gray matter. Brain and mind are related, and this relationship works to do think which stored in memory. It transmits timely from a store and hits mind that what happened in the past. In the present situation, the mind has determinable property. But for the future, which we think for tomorrow, all-time it may not be applicable due to variation of the present situation. A couple system is a system of dual property between two objects (A) \& (B) related to the third party (R). This third party ordered to do function. Suppose, he loves a girl, love comes out from the mind; here mind is a third property which calls each other to meet in the form of the direction of love. A figure is given here, for an example: 


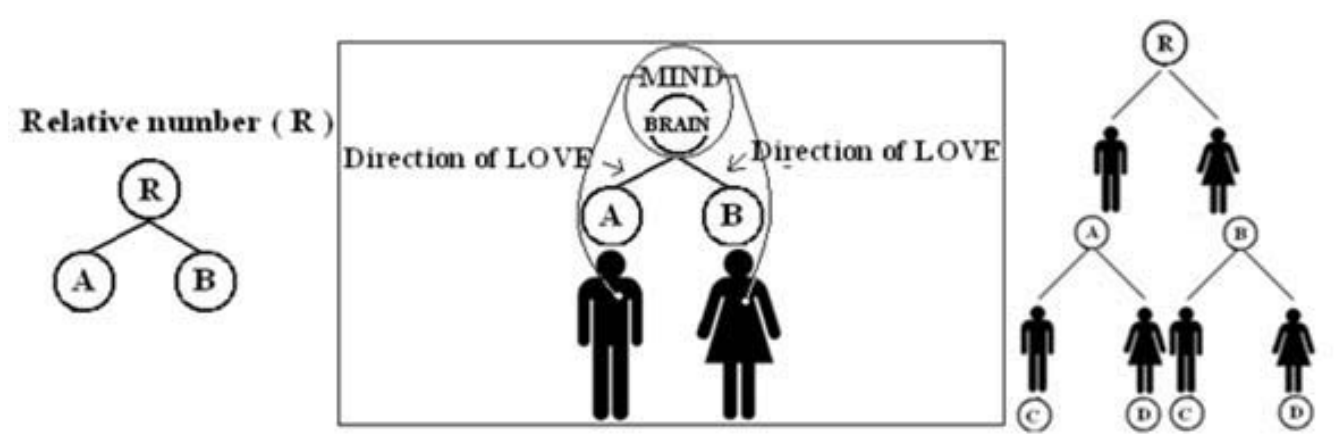

Couple system is related to Mind and Brain

Fig. 28

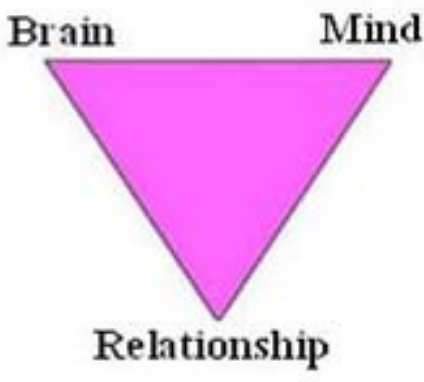

Fig. 29

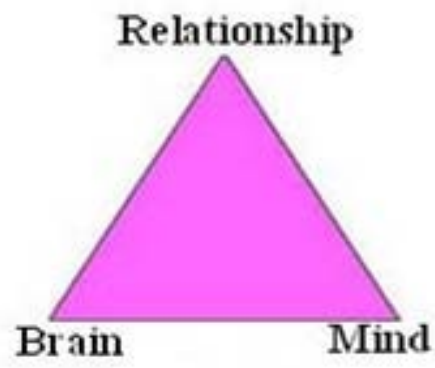

Fig. 30

[Reference - 77] [From the view of Couple System]

A taken from Reference and Figure -30 is the reverse of Figure - 29 and obeying the figure of Couple System In figure -28 , we see that $A$ \& $B$ is related to $R$. This $R$ may term as RELATIVE NUMBER between $A$ \& $B$. This relation will continue when the series extend from $A \& B$ to $C \& D$ to keep relation $R$. Let, $A$ \& $B$ placed in $A$ zone and $B$ zone respectively, and $C \& D$ will produce another zone as $C$ zone and $D$ zone. If $C \& D$ another two number makes relation to $A \& B$ together, then the zone may be represented by a round symbol as, and we can write it in the form of:

No. 1, Formation:

The Reaction of a couple:

If $A \& B$ takes place in the form of $A+\& B+$ in the positive zone and $C \& D$ takes place in the negative zone in the form of $D-\& C+$ related to $A+\& B+$ in the positive zone, then if dressed it in the form of:

$R \rightarrow(D-. A+C+B+)$, we can write, $D-=-D \& C+=+C$

$R \rightarrow(C . A+C . A)$

$\mathrm{R} \rightarrow 2 \mathrm{CA}$

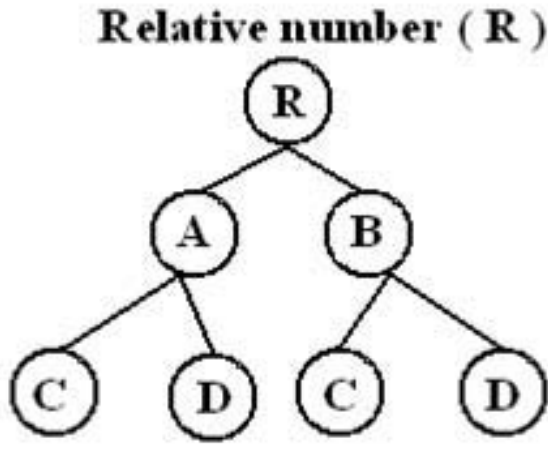

Fig. 31

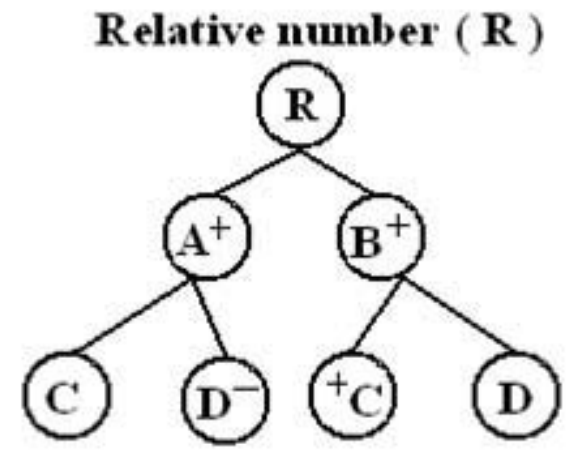

Fig. 32 
The Reaction of a couple:

If $A \& B$ takes place in the form of $A^{+} \& B^{+}$in the positive zone and $C \& D$ takes place in the negative zone in the form of $D^{-} \& C^{+}$related to $A+\& B+$ in the positive zone, then if dressed it in the form of:

$R \rightarrow\left(D^{-} . A+C^{+} \cdot B^{+}\right)$, we can write, $D^{-}=-D \& C^{+}=+C$

$R \rightarrow(C . A+C . A)$

$\mathrm{R} \rightarrow 2 \mathrm{CA}$

\section{Description:}

1) $D$ is related to $A$ (Fig-31, L.H.S.), and $C$ to $B$ (Fig -32, R.H.S.). But the value of $A$ and $C$ will be same as the value of $B$ and D. D- in L.H.S. means that it is the end of the reaction of the problem to form relative number $(R)$ acting with $\mathrm{C}+$ in R.H.S.

2) The original value of $D$ is $C$; therefore, $D$ reacts with $A$ and forms $C A$. Similarly, $C$ is the value of $D$, but the real value of $B$ is $A$. So, $C$ reacts with $B$ and forms $C A$.

3) The total couple reaction with respect to $R$ is $2 C A$.

When the value of $A, B, C, D \ldots$, individual, then the result of 2 CA will bring another number [1].
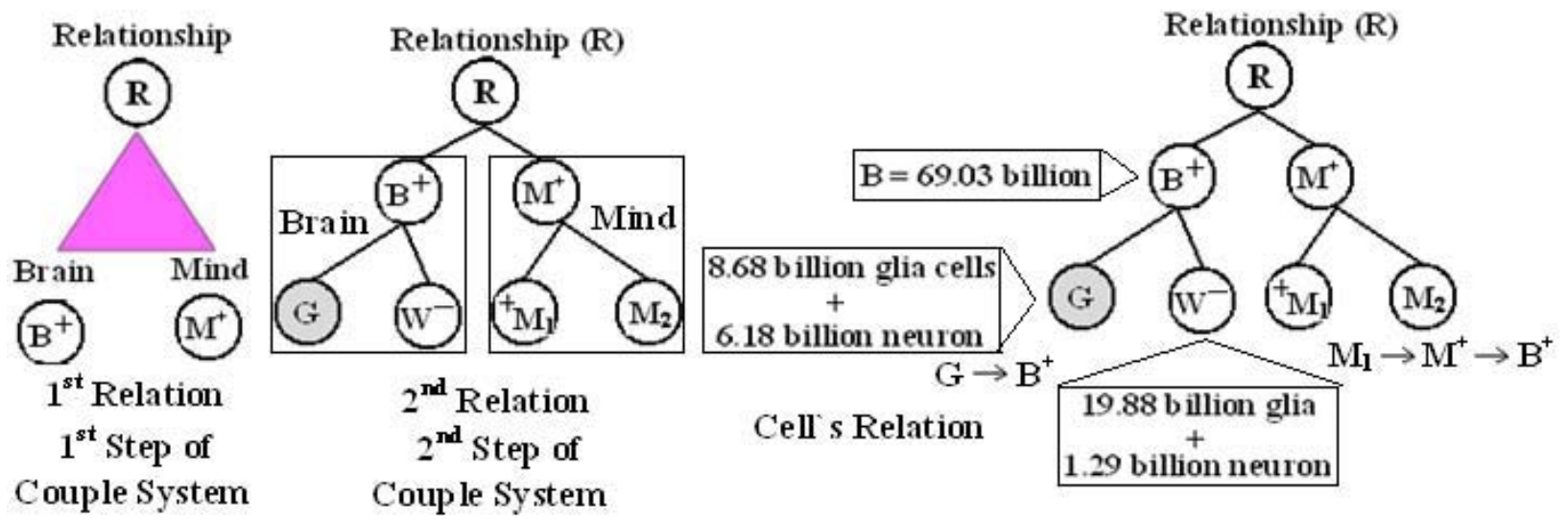

Fig. 33

Here in this figure- 33, suppose, $\mathrm{R}=$ Relation between Brain and Mind $=1$ Brain +1 Mind $=2$

Total neuron in the brain, $\mathrm{B}=69.03$ billion, $\mathrm{M}^{+}=$Conscious mind

$\mathrm{G}=$ Gray Matter (8.68 billion glia cells +6.18 billion neuron cells),

$\mathrm{M}_{1}=$ Same to Conscious mind, $\mathrm{M}_{2}=$ Sub Conscious mind

Effect of Gray Matter by Couple System: (Figure - 33)

$R \rightarrow 8.68$ billion glia cells $\times 69.03$ billion neuron cells in brain $+M_{1} \times 69.03$ billion neuron cells

Or, $R \rightarrow 599.1803$ billion neuron cells ${ }^{2}+M_{1} \times 69.03$ billion neuron cells.

Or, $M_{1} \times 69.03$ billion neuron cells +599.1803 billion neuron cells ${ }^{2}=2$ billion cells ${ }^{2}$ need for couple (Assuming that at least 2 billion cells ${ }^{2}$ need for function where, $R=1$ brain +1 mind $=2$ )

Or, $M_{1} \times 69.03$ billion neuron cells $=2$ billion neuron cells ${ }^{2}-599.1803$ billion neuron cells ${ }^{2}=-597.1803$ billion $^{2}$.

Or, $M_{1}=-599.1803$ billion neuron cells ${ }^{2} / 69.03$ billion neuron cells $=-8.65102$ billion neuron cells will function mind.

This value 8.65 billion is almost $1 / 10^{\text {th }}$ of 86.1 billion neuron cells out of total of 170.68 billion cells in the brain [75]. - negative sign indicating that mind on functioned to do give the order to work, which is mind-minus. When any view/ think/ ..., enter into brain, then we may call it mind-plus. These two compartments (+Memory \& Memory) are very active for the living body. We keep it in mind and stored in memory.

Effect of white matter from the view of a couple systems. (Figure - 33)

$R \rightarrow 19.88$ billion glia cells $\times 69.03$ billion neuron cells in brain $+M_{1} \times 69.03$ billion neuron cells.

Or, $R \rightarrow 1371.779$ billion neuron cells ${ }^{2}+M_{1} \times 69.03$ billion neuron cells

Or, $M_{1} \times 69.03$ billion neuron cells +1371.779 billion neuron cells ${ }^{2}=2$ billion cells ${ }^{2}$ need for couple

Or, $M_{1} \times 69.03$ billion neuron cells $=2$ billion neuron cells ${ }^{2}-1371.779$ billion neuron cells ${ }^{2}=-1369.779$ billion$^{2}$.

Or, $M_{1}=-1369.779$ billion neuron cells ${ }^{2} / 69.03$ billion neuron cells $=-198.432$ billion neuron cells will function mind. 
For the white region, (Figure - 34, R.H.S.)

Effect of mind $=198.432$ billion neuron cells $\times 1.29$ billion cells / ( 8.68 billion glia +6.18 billion neuron $)=-17.225$ billion cells which is almost $1 / 10^{\text {th }}$ of 170.68 billion cells of human brain.

This value 8.61 billion is almost $1 / 10^{\text {th }}$ of 86.1 billion neuron cells out of total of 170.68 billion cells in the brain [74]. The negative sign indicating that mind on functioned to do give the order to work.

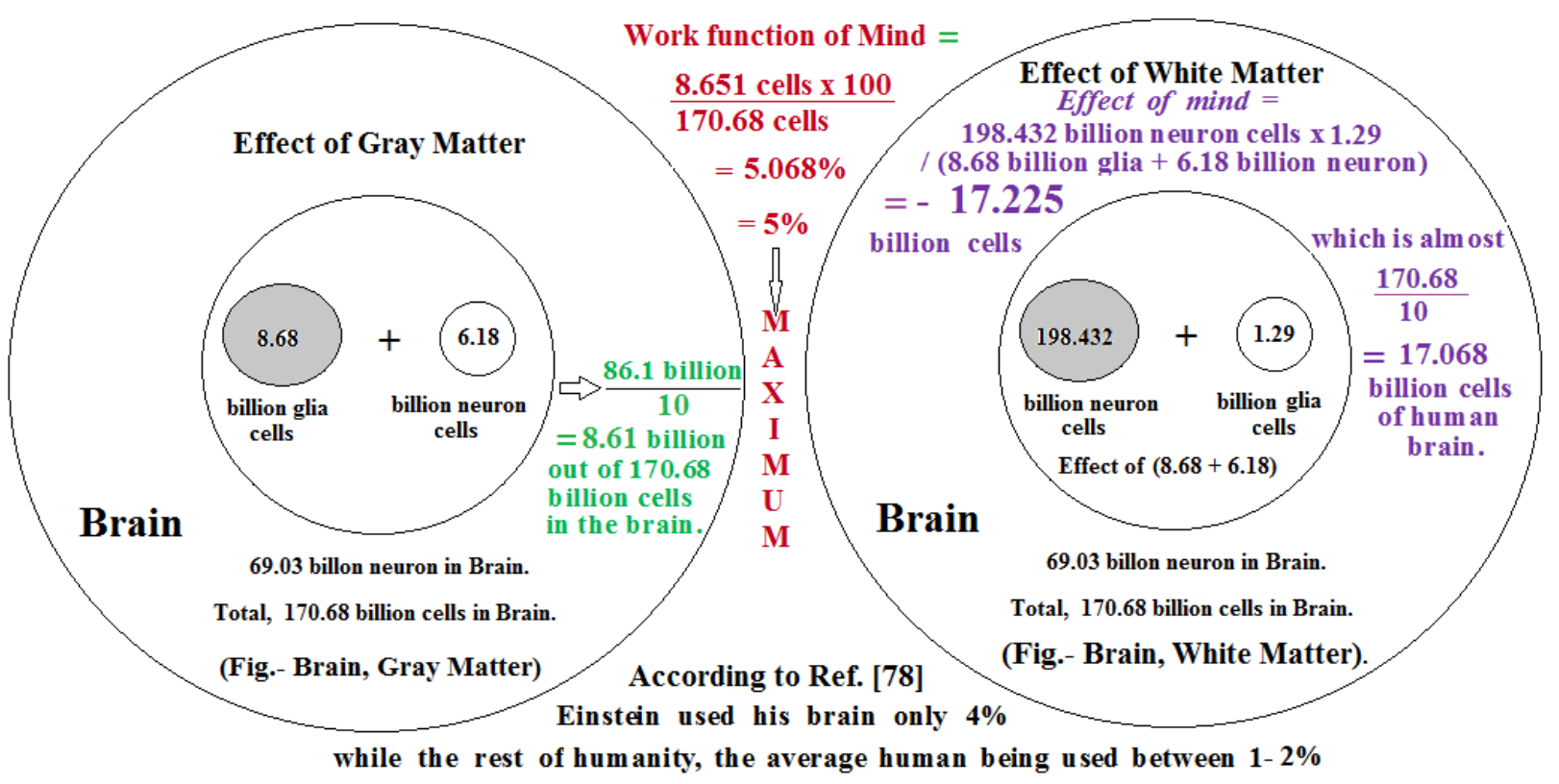

Fig. 34

How many percentage cells work for mind?

For figure - Brain, Gray Matter: (Fig.- 34, L.H.S.)

Work function of the mind $=8.65102$ billion cells $\times 100 / 170.68$ billion cells $=5.068 \%=5 \%$. Only $5 \%$ of cells function for mind in the brain. According to reference [78], Vijay Kumar, who Realized God In 1993 - the connecting link between human form - cosmic mind. He said, "Albert Einstein used his brain only $4 \%$ while the rest of humanity, the average human being used between $1-2 \%$, the balance portion always lying dormant. The human brain primarily acts as a receiving and transmitting station. No human being ever had an independent mind. The mind of the entire cosmos is one; it had only two compartments... reservoir of mind plus and reservoir of mindminus".

\section{For Figure - Brain, White Matter: (Fig.- 34, R.H.S.)}

In the white region, this effect will, 17.225 billion cells $\times 100 / 170.68$ billion cells $=10.09 \%=10 \%$. According to reference [79], nearly 90 percent of the brain is composed of glial cells, not neurons. Andrew Koob argues that these overlooked cells just might be the source of the imagination. Astrocytes are also the adult stem cell in the brain and control blood flow to regions of brain activity. Because of all these important properties, and since the cortex is believed responsible for higher thought, scientists have started to realize that astrocytes must contribute to thought. Calcium waves in the cortex are leading scientists to infer that this style of communication may be conducive to the processing of certain thoughts. This idea stems from dreams, sensory deprivation. Without input from our senses through neurons, how is it that we have such vivid thoughts? How is it that when we are deep in thought, we seemingly shut off everything in the environment around us? In this theory, neurons are tied to our muscular action and external senses. We know astrocytes monitor neurons for this information. Similarly, they can induce neurons to fire. Therefore, astrocytes modulate neuron behavior. This could mean that calcium waves in astrocytes are our thinking mind. Neuronal activity without astrocyte processing is a simple reflex; anything more complicated might require astrocyte processing.

From the above writings, we can assume that, for ordinary people used less than $4 \%$ comparing Einstein `s brain. Though that will vary from time to time depending on age, brain weight, power of thinking, keeping capacity of the memory of the brain. Altogether, in all cases, mind will touch the field of the body. The brain has capacity $100 \%$ to do work, anyone can cover this field. But this is very tub to do. Because we are losing memory, we do not keep the mind in attention in the same direction concerning time. Due to these reasons, a lot of things went out of the 
memory which plays with the mind. The function of memory comes from the brain and remarkable memory stored in it; when the mind wishes to search and order to the brain, then it comes out, and we describe on that past facts. Again, we lost many memories every day. Suppose the most common matter, the sun is rising, we are observing this, but we do not keep in mind. That is the uses of everyday things sometimes ignore the mind. But in the case of the sexual field, most of the persons (Men \& Women) want to meet together to get their mental and sexual satisfactions. These two opposite nature of the body always wants to attract each other. Due to our social construction, we can't meet an unknown men or women to do sex work. For example, when a beautiful lady passing you, your mind attracts her by eyes and action to be start in your mind that, Oh! Shall I marry her? May I use it? Soso thinks stored in your brain as memory. It is very difficult to explain perfectly about the mind and its behavior connected to the brain. Again, the brain is connected to every parts of the body; mind also obeys this path with brain activity. If I feel pain in my body, immediately brain will attain in that place and my mind does not think other on that moment, I shall not think on universe, planets, other picture, wife, person etc. how I get pain or how I can relieve from it, that will be main feature at that time. Therefore, our mind will work maximum 5 billion cells with effect of 10 billion cells of brain as shown in the Figure: Brain, Gray Matter and Brain, White Matter.

\section{Conclusion}

Lot of examples is there, the relative number obtained from couple system naturally important. We can apply it in other fields. Body cell is most important, body fit means mentally fit. So need such discover equipment by which cell in a body will stay in normal position. Math is manmade properties; its application to nature helps us to increase the knowledge many ways.

\section{References Références Referencias}

1. Nirmalendu Das, A couple systems to find the different series of Pi. International Journal of Mechanical Engineering And Information Technology. (IJMEIT) ijetae@gmail.com, ID Number: IGM 1332/E, ISSN No: 2348196X, Volume 03, Issue 07, July 2015,Page No: 1437 - 1445.

2. Nirmalendu Das, The series of $1 / 2$ and other applications by using the Relative Numbers which yielded from Couple Systems. International Journal of Mathematics, ijoar.editor@gmail.com, ID - IJOARM-3597. Volume 3, Issue 7, July 2015 Edition.

3. Nirmalendu Das, Searching of Properties of Mind, activity of number of cells in a Brain by Couple System. Journal of Cell Science \& Molecular Biology, Volume 2, Issue 1 - 2015. 21-12-2015.

4. Nirmalendu Das, International Journal Of Information Research And Review, Determination of Relative Numbers By Using Couple Systems And Its Application To The Atomic Fields and Quark Coupling Strength, Tallied Experiment of the Lhcb Collaboration, July 2015, 30th, December 2015.

5. Oogenesis-Wikipedia, en.wikipedia.org/wiki/ Ooge-nesis

6. Sex cells and chromosomes. The Reproductive System-Encyclopedia.com,www.encyclopedia.com/ doc/1G23437000030.html, Gonad (GO-nad): Sex organ in which reproductive cells develop. Greater Menopause (MENah-paws): Period in a woman's life when menstrual activity ceases. Menstruation. It also serves as a lubricant during sexual intercourse.

7. Gestation Periods - Human \& Other Mammals - Vaughn's Summaries www.vaughns -1- pagers.com /.../ gestation-periods.htm

8. Your Baby's Development: The First Trimester familydoctor.org > Home , Pregnancy \& Newborns , Fetal Health.

9. What Is Cancer?- National Cancer Institute, www.cancer.gov/about-cancer/understanding/ what...

10. The Reproductive System - Encyclopedia.com, www.encyclopedia.com/doc/1G2-3437000030.html, Gonad (GO-nad):

11. Cancer cell - Wikipedia, the free encyclopedia, https://en.wikipedia.org/wiki/Cancer_cell

12. Cancer Cell Division Images, Stock Photos \& Vectors | ...Ad.www.shutterstock.com/

13. Brain Basics: The Life and Death of a Neuron | National ... www.ninds.nih.gov/.../Life-and-Death-Neuron

14. [37] [39] From Wikipedia, the free encyclopedia "Glia" redirects here. For the scientific journal, see Glia (journal)

15. How Many Hairs Are on the Human Head? Averages and Facts www.healthline.com/health /how-many-hairsona...

16. Why are over 250 million sperm cells released ... - Scienceline, scienceline.org/2008/06/ask-olson-sperm

17. Brain Facts and Figures https://faculty.washington. edu/chudler/facts.html

18. Human eggs: How many and for how long? | Go Ask Alice! goaskalice.columbia. edu/answeredquestions/ human...

19. Microbes in the human body (MPKB), mpkb.org, homes pathogenesis, microbiota According to Asher Mullard, "Between them [the bacteria in our bodies], they harbor millions of 
20. Quantifying Human Information Processing, books.google.co.in books Dennis K. McBride, - worromhcS nalyD 2005lacideM

21. Inner hair cells (IHCs): Stucture|Cochlea, www.cochlea.eu> hair-cells; inner-hair-cells-ihcs-stucture

22. [30] Retinal ganglion cell-Wikipedia en.wikipedia.org/wiki/Retinal_ganglion_cell

23. Stereologic analysis of the lateral geniculate nucleus of the thalamus in normal and schizophrenic subjects. Selemon LD, Begovic A, Psychiatry Res. 2007 May 30; 151(1-2):1-10.

24. J Neurosci Methods. 1990 Feb;31(2):93-100. An efficient method for estimating the total number of neurons in rat brain cortex. Korbo L1, Pakkenberg B, Ladefoged O, Gundersen HJ, Arlien-Søborg P, Pakkenberg H.

25. Transmitting fibers in the brain: Total length and distribution of The largest and most famous white matter tract in the human brain is the corpus callosum, which connects the two hemispheres and contains 200-250 million fibers, about as many as one can find in tracts connecting areas within hemispheres.Mar 29, 2018.

26. Brain Facts and Figures-University of Washingtonfaculty.washington.edu/chudler/facts. Html

27. [44] [48] [49] [50][56] [68] [69] [70] [71] [72] List of animals by number of neurons, From Wikipedia the free encyclopedia. Understanding Your Lab Test Results - American Cancer ... www.cancer.org s content , dam > CRC , PDF , Public.

28. Memory B cell - Wikipedia, en.wikipedia.org/wiki/Memory_B_cells

29. [45][67] 37.2 Trillion: Galaxies or Human Cells? - The New York Times.

30. The nervous system: more than 90,000 miles of sensations ... www.ikonet.com/en/visualdictionary/ static/us/the nervous...

31. WBC (White Blood Cell) Count: Purpose, Procedure, and Results www.healthline.com/health / wbc-count

32. Adipocyte-Wikipedia, en.wikipedia.org/wiki/Adipo-cyte

33. (PDF) An estimation of the number of cells in the human body www.researchgate.net/publication $/ 248399628$

34. There are 37.2 Trillion Cells in Your Body | Smart News www.smithsonianmag.com/smart-news/ there-are-372...

35. Scalable Neuroscience and the Brain Activity Mapping Project cs.brown.edu/people/tld/note/b/og /13/04/19/

36. How many neurons make a human brain? Billions fewer than we ...www.theguardian.com/ .../how-manyneuronshuman-brain

37. Why Are 250 Million Sperm Cells Released During Sex? | Live ...www.livescience.com/32437-why-are-250million... Jan 24, 2013 - In fact, the average male will produce roughly 525 billion sperm cells over a lifetime and shed at least one billion of them per month. A healthy adult male can release between 40 million and 1.2...

38. How many brain cells do we lose per day? | Yahoo Answers answers.yahoo.com/question/index?qid=.

39. [52] Brain Facts and Figures - University of Washington faculty.washington.edu/chudler/facts. html Number of synapses for a "typical" neuron $=1,000$ to 10,000

40. Which animal has the highest number of brains? | Answers Drive, answersdrive.com/which-animal-hasthehighest- number-of-brains-1360277

41. [53] Virtual memory $T$ cells develop and ... - PubMed Central (PMC) www.ncbi.nlm.nih.gov/pmc/articles/ PMC4844673 Apr 21, 2016 - It has become increasingly clear that memory T cells possess substantial innatelike ... Consciousness in a Cockroach|Discover Magazine www.discovermagazine.com smind consciousnessin-acockroach

42. Photoreceptor cell - Wikipedia en.wikipedia.org/wiki/ Photoreceptor_cell The human retina contains about 120 million rod cells, and 6 million cone cells. The number and ratio of rods to cones varies among species.

43. Neocortical neuron number in humans: effect of sex and age. www.ncbi.nlm.nih.gov/pubmed/9215725 Jul 28 , 1997. The average numbers of neocor-tical neurons were 19 billion in female brains and 23 billion in male brains, a $16 \%$ difference. In our study, which covered the age range from 20 years to 90 years,

44. List of animals by number of neurons - Wikipedia, the free ... https: //en.wikipedia.org/wiki/ List_of_animals by number_of neurons. This is a list of representative animals by the number of neurons in their

45. [61] [62] Mar 10, 2011 - Primary glial cell cultures are the most commonly used in vitro model for neurobiological studies. However, the lack of an easy and fast protocol ... An easy and fast way to obtain a high number of glial cells from rat cerebral tissue: A beginners approach.

46. If Elephants Have Bigger Brains, Why Are They Not Smarter ...[B] neuroscienceschool.com /2017/07/04 /elephants... Jul 04, 2017. The African elephant brain had three times the number of neurons in a human brain, 257 billion to our 86 billion. But, $98 \%$ of their neurons were located in the cerebellum, in the back of the brain. That left 5.6 billion neurons.

47. [64] Front Neuroanat. 2014; 8: 132., Published online 2014 Nov 26. doi: 10.3389/fnana. 2014.00132 Quantitative relationships in delphinid neocortex, Heidi S. Mortensen,1,2 Bente Pakkenberg,1 Maria Dam, 2 Rune Dietz, 3Christian Sonne, 3 Bjarni Mikkelsen,4 and Nina Eriksen1, * Author information Article notes Copyright and License information Disclaimer. 
48. Number of Neurons in a Human Brain - The Physics Factbook hypertextbook.com/facts/2002/Anicia Ndabahaliye2... "The human brain has from 10 billion to 100 billion neurons." 10-100 billion: Magill's Medical Guide Revised Edition. Salem Press, 1998: 221.

49. How Many Atoms Are There in a Human Cell? www.thoughtco.com/how-many-atoms-in-human-cell-603882.

50. There are 37.2 Trillion Cells in Your Body|Smart News ... www.smithsonianmag.com/smart-news/ there-are372... Oct 24, 2013 - There are 37.2 Trillion Cells in Your Body ... Calculating the number of cells in the human body is tricky. Part of the problem is that using different metrics gets you very different outcomes ...

51. List of animals by number of neurons - Wikipedia en.wikipedia.org/wiki/ Lis_of animals_by_number... The second list shows the number of neurons in their forebrain, a measure which has been found to be representative of animal intelligence. In mammals.

52. Know Your Neurons: What Is the Ratio of Glia to Neurons in ...blogs.scientificamerican.com/ brainwaves/knowyour- neurons-what-is-th...

53. What is Grey Matter? - News Medical www.news-medical.net/health/What-is-Grey-Matter.aspx Nov 5, 2014 Also found in the grey matter are the glial cells (astroglia and ... The cerebrum is where the more complex brain functions occur and in humans ...

54. What's The Difference Between The Mind And The Brain ...www.thebestbrainpossible.com/the-mind-and-the brain-what-is-the-diffe...Equally surprising to me is that, by default, a healthy mind is generally thought ... which is the capacity of the brain to create new neural connections and grow new ... I think we all have to work out definitions of the mind and brain, our physical.

55. Is it true that Albert Einstein used $7 \%$ of his brain, while the ... https://www.quora.com/ls-it-true-that-AlbertEinstein-used-7-of-his-brain-... 2. His corpus callosum had mre fibre connections between the two hemis...... Is it true that Albert Einstein used $7 \%$ of his brain, while the average human being uses ... The whole brain percentage idea is a myth, see Ten percent of brain myth.

56. The Root of Thought: What Do Glial Cells Do? - Scientific ...www.scientificamerican.com>Mind`Mind Matters Oct 27, 2009 - Nearly 90 percent of the brain is composed of glial cells, not neurons.... Mind Matters editor Jonah Lehrer chats with Koob about why glia have ... of glialcells, which actually make up nearly 90 percent of cells in the brain. ... ("The Neuron Doctrine" is a belief that neurons are responsible for our thoughts.) ...

57. Coronavirus disease 2019 - Wikipedia en.wikipedia.org/wiki/Coronavirus_disease_2019 Coronavirus disease 2019 (COVID-19) is an infectious disease caused by severe acute respiratory syndrome coronavirus 2 (SARSCoV-2). The disease was first identified in 2019 in Wuhan, the capital of Hubei province in central China, and has since spread globally, resulting in the 2019-20 coronavirus pandemic.

58. Modelling The Spread Of Covid-19 Forecasting the spread of COVID-19, including the likely number of undetected cases, is fraught and difficult, but a sense of the numbers is important for appreciating the challenges ahead. By Associate Professor Ben Phillips, University of Melbourne.

59. [61] [62] Mar 10, 2011 - Primary glial cell cultures are the most commonly used in vitro model for neurobiological studies. However, the lack of an easy and fast protocol ... An easy and fast way to obtain a high number of glial cells from rat cerebral tissue: A beginners approach.

60. If Elephants Have Bigger Brains, Why Are They Not Smarter ...[B] neuroscienceschool.com /2017/07/04/elephants... Jul 04, 2017 . The African elephant brain had three times the number of neurons in a human brain, 257 billion to our 86 billion. But, $98 \%$ of their neurons were located in the cerebellum, in the back of the brain. That left 5.6 billion neurons.

63. [64] Front Neuroanat. 2014; 8: 132., Published online 2014 Nov 26. doi: 10.3389/fnana. 2014.00132 Quantitative relationships in delphinid neocortex, Heidi S. Mortensen,1,2 Bente Pakkenberg,1 Maria Dam,2 Rune Dietz,3Christian Sonne, 3 Bjarni Mikkelsen,4 and Nina Eriksen1,* Author information Article notes Copyright and License information Disclaimer.

65. Number of Neurons in a Human Brain - The Physics Factbook hypertextbook.com / facts /2002 / AniciaNdabahaliye2... "The human brain has from 10 billion to 100 billion neurons." 10-100 billion: Magill's Medical Guide Revised Edition. Salem Press, 1998: 221.

66. How Many Atoms Are There in a Human Cell? www.thoughtco.com/how-many-atoms-in-human-cell-603882.

73. There are 37.2 Trillion Cells in Your Body | Smart News ... www.smithsonianmag.com/smart-news/there-are$372 \ldots$ Oct 24, 2013 . There are 37.2 Trillion Cells in Your Body ... Calculating the number of cells in the human body is tricky. Part of the problem is that using different metrics gets you very different outcomes

74. List of animals by number of neurons - Wikipedia en.wikipedia.org/wiki/ Lis_of_animals_by_number... The second list shows the number of neurons in their forebrain, a measure which has $\bar{b} \overline{-} \overline{-}$ found to be representative of animal intelligence. In mammals,

75. Know Your Neurons: What Is the Ratio of Glia to Neurons in ...blogs.scientificamerican.com / brainwaves/knowyour-neurons-what-is-th... 
76. What is Grey Matter? - News Medical www.news-medical.net/health/What-is-Grey-Matter.aspx Nov 5, 2014 Also found in the grey matter are the glial cells (astroglia and ... The cerebrum is where the more complex brain functions occur and in humans...

77. What's The Difference Between The Mind And The Brain ...www.thebestbrainpossible.com/the-mind-and-thebrain-what-is-the-diffe...Equally surprising to me is that, by default, a healthy mind is generally thought ... which is the capacity of the brain to create new neural connections and grow new ... I think we all have to work out definitions of the mind and brain, our physical

78. Is it true that Albert Einstein used $7 \%$ of his brain, while the ... https://www.quora.com/ls-it-true-that-AlbertEinstein-used-7-of-his-brain-... 2. His corpus callosum had mre fibre connections between the two hemis...... Is it true that Albert Einstein used $7 \%$ of his brain, while the average human being uses... Thewhole brain percentage idea is a myth, see Ten percent of brain myth.

79. The Root of Thought: What Do Glial Cells Do? - Scientific ... www.scientificamerican.com > Mind > Mind Matters Oct 27, 2009 - Nearly 90 percent of the brain is composed of glial cells, not neurons.... Mind Matters editor Jonah Lehrer chats with Koob about why glia have ... of glialcells, which actually make up nearly 90 percent of cells in the brain. ... ("The Neuron Doctrine" is a belief that neurons are responsible for our thoughts.) ...

80. Coronavirus disease 2019 - Wikipedia en.wikipedia.org/wiki/Coronavirus disease 2019 Coronavirus disease 2019 (COVID-19) is an infectious disease caused by severe acute respiratory syndrome coronavirus 2 (SARSCoV-2). The disease was first identified in 2019 in Wuhan, the capital of Hubei province in central China, and has since spread globally, resulting in the 2019-20 coronavirus pandemic.

81. MODELLING THE SPREAD OF COVID-19

Forecasting the spread of COVID-19, including the likely number of undetected cases, is fraught and difficult, but a sense of the numbers is important for appreciating the challenges ahead. By Associate Professor Ben Phillips, University of Melbourne. 